\title{
Influence of Material Deprivation on Clinical Outcomes Among People Living with HIV in High-Income Countries: A Systematic Review and Meta-analysis
}

\author{
Vasiliki Papageorgiou $^{1}\left(\mathbb{D} \cdot\right.$ Bethan Davies $^{2}\left(\mathbb{D} \cdot\right.$ Emily Cooper $^{1}\left(\mathbb{D} \cdot\right.$ Ariana Singer $^{3} \cdot$ Helen Ward $^{1}$ (D)
}

Accepted: 27 November 2021 / Published online: 11 December 2021

(c) The Author(s) 2021

\begin{abstract}
Despite developments in HIV treatment and care, disparities persist with some not fully benefiting from improvements in the HIV care continuum. We conducted a systematic review to explore associations between social determinants and HIV treatment outcomes (viral suppression and treatment adherence) in high-income countries. A random effects meta-analysis was performed where there were consistent measurements of exposures. We identified 83 observational studies eligible for inclusion. Social determinants linked to material deprivation were identified as education, employment, food security, housing, income, poverty/deprivation, socioeconomic status/position, and social class; however, their measurement and definition varied across studies. Our review suggests a social gradient of health persists in the HIV care continuum; people living with HIV who reported material deprivation were less likely to be virologically suppressed or adherent to antiretrovirals. Future research should use an ecosocial approach to explore these interactions across the lifecourse to help propose a causal pathway.
\end{abstract}

Keywords Antiretroviral therapy $\cdot \mathrm{HIV} \cdot$ Meta-analysis $\cdot$ Social determinants of health $\cdot$ Socioeconomic factors Systematic review $\cdot$ Viral suppression

\section{Resumen}

A pesar de los avances en el tratamiento y la atención al VIH, ciertas desigualdades persisten en estas áreas. Como resultado, algunas personas que viven con el VIH no se benefician plenamente de las mejoras en la atención del VIH a todos los niveles. Realizamos una revisión sistemática para explorar las asociaciones entre los determinantes sociales de la salud y los resultados del tratamiento del VIH (supresión viral y tratamiento de adherencia) en países de ingresos altos. Completamos un metaanálisis siguiendo un modelo de efectos aleatorios e incluyendo medidas consistentes de exposiciones. Identificamos 83 estudios observacionales elegibles para inclusión. Los determinantes sociales vinculados a las circunstancias materiales (privación) se identificaron como educación, empleo, seguridad alimentaria, vivienda, ingresos, pobreza / privación, situación / posición socioeconómica y clase social; sin embargo, su medición y definición variaron entre los estudios. Nuestro estudio sugiere que un gradiente de salud social persiste en la atención sanitaria del VIH a todos los niveles; las personas que viven con el VIH que declaran privación material tenían menos probabilidades de alcanzar la supresión viral o de ser adherente a los antirretrovirales. Futuras investigaciones deberían utilizar un enfoque ecosocial para explorar estas interacciones a lo largo del curso de la vida para ayudar a proponer una vía causal.

Vasiliki Papageorgiou

vasiliki.papageorgiou17@imperial.ac.uk

1 Patient Experience Research Centre, School of Public Health, Imperial College London, London, UK

2 Department of Epidemiology and Biostatistics, School of Public Health, Imperial College London, London, UK

3 School of Public Health, Imperial College London, London, UK

\section{Abbreviations}

aHR

aOR

aPR

aRR

ART

cART

CI

$\mathrm{CSDH}$
Adjusted Hazard Ratio

Adjusted Odds Ratio

Adjusted Prevalence Ratio

Adjusted Relative Risk

Antiretroviral therapy/treatment

Combination antiretroviral therapy

Confidence interval

WHO Commission on Social Determinants of Health 


$\begin{array}{ll}\text { EPICES } & \begin{array}{l}\text { Evaluation of Deprivation and Inequalities in } \\ \text { Health Examination Centres }\end{array} \\ \text { FPL } & \text { Federal Poverty Level } \\ \text { HAART } & \text { Highly active antiretroviral therapy } \\ \text { HFSSM } & \text { Household Food Security Survey Module } \\ \text { MEMS } & \begin{array}{l}\text { Medication Event Monitoring Systems } \\ \text { NICE }\end{array} \\ & \begin{array}{l}\text { National Institute for Health and Care Excel- } \\ \text { lence (UK) }\end{array} \\ \text { OECD } & \begin{array}{l}\text { Organisation for Economic Co-operation and } \\ \text { Development } \\ \text { SEP/SES }\end{array} \\ \text { Socioeconomic position/status } \\ \text { VL }\end{array}$

\section{Introduction}

The social determinants of health describe the conditions in which a person is "born, grows, lives, works and ages" and operate alongside social hierarchy, socioeconomic position, power differentials and the wider socioeconomic and political context [1]. Less privileged and marginalised individuals experience poorer health outcomes than the general population which can, in part, be attributed to current and historical struggles with structural racism, discrimination, recurring inequalities and social exclusion [1-4]. Recent evidence suggests that a decade of government austerity has led to widening health, social and economic inequalities in countries, such as England, that have resulted in stalling life expectancy, declining social mobility and increased food insecurity $[5,6]$.

Inequalities persist among people living with HIV globally despite advancements in life expectancy, treatment and care. Some groups are disproportionately affected including migrants, the homeless and sex workers [7-11]. These disparities are underpinned by social and structural factors including gender, sexual orientation, ethnicity, racism and socioeconomic position which influence an individual's agency and power within a specific context $[12,13]$. A literature review by Burch et al. [14] reported that people living with HIV who had poorer socioeconomic status (SES) were more likely to have poorer virological and immunological responses to antiretroviral therapy (ART). The authors defined SES according to material factors (e.g., education, neighbourhood socioeconomic position) and the health system (e.g., health insurance) itself $[1,14]$. In countries without universal healthcare systems, such as the US, publicly funded systems of care exist to support individuals who are uninsured access healthcare; for instance, the Ryan White HIV/AIDS Program [15, 16]. However, the funding, accessibility and eligibility requirements of these services are influenced by structural determinants including the political systems, structures, policies and leadership in which they exist and operate.
For people living with HIV, adhering to prescribed antiretrovirals is essential to maintain virological suppression and to reduce the risk of drug resistance [17, 18]. Early research [19] estimated that HIV-1 viral load (VL) can be reduced by approximately $99 \%$ within two weeks of treatment initiation (using protease inhibitors and reverse transcriptase inhibitors). The level of ART adherence required to reach viral suppression is now considered to be regimendependent and could be as low as $75 \%$ for some [20]. Successful treatment and viral suppression are the second and third UNAIDS 90:90:90 targets; several high-income countries including the UK, Denmark and the Netherlands met these targets before the deadline of 2020 [21, 22]. Referral to, and retention in, HIV care services is therefore critical. However, this is dependent on early diagnosis which is not always achieved; in the UK in 2019, it was estimated that approximately $42 \%$ of people living with HIV were diagnosed late, defined by a CD 4 count at diagnosis of $<350$ cells $/ \mathrm{mm}^{3}[23,24]$. The percentage of late diagnoses varied according to age, ethnicity and mode of transmission, with the highest proportion (52\%) among heterosexual men [23, 24].

Social determinants exist within complex, intersectoral systems, can be highly correlated and are driven by the context in which they are created and manifest $[1,25]$. We build on the definition of social determinants by the WHO Commission on Social Determinants of Health (CSDH) framework to include the "intermediary determinants" of living circumstances, working conditions and food availability [1]. We frame our findings in relation to Krieger's ecosocial theory which aims to understand how "health inequities constitute biological expressions of injustice" across societal and ecosystem levels, pathways and power differentials [13, 26-28]. Ecosocial theory attempts to unpick the complexity of interactions across ecologies; for instance, the scale of phenomena (including measured and unmeasured factors), how these are organised (hierarchies) and spatiotemporal dynamics which means they are restricted by the extent to which these have been previously theorised, conceptualised, inferred and explored [27]. Much like ecosocial theory, the social production of disease and/or political economy of health as well as psychosocial theory can help elucidate how and why diseases are unevenly distributed across societies as well as implications for action [27]. We focus on factors of material deprivation, which could be targeted by social and public health policies.

Our aim is to synthesise the evidence and identify the social determinants that have an impact on HIV treatment outcomes (specifically viral suppression, ART adherence) among people living with HIV in high-income countries. 


\section{Methods}

We conducted a systematic review using the PRISMA 2020 checklist (Additional file 1); a full protocol is published on PROSPERO (identification number: CRD42020171850) $[29,30]$. We adapted the approach of Burch et al.[14] to provide a more recent examination of the association between social determinants and HIV treatment outcomes; however, we focus on observational studies (cohorts and cross-sectional studies), rather than randomised controlled trials, as these replicate real-world settings.

\section{Search Strategy and Selection Criteria}

We searched MEDLINE, EMBASE, Global Health, HMIC, Cochrane Library, CINAHL, Web of Science, ProQuest and Scopus databases from date of creation (or first stored record) to 13 January 2020 using a search strategy developed with a University librarian. We also hand searched conference databases until March 2020 and searched the reference lists of relevant review articles and editorials. Further detail, including search strategies, are provided in Additional file 2.

Studies were assessed for eligibility using the criteria detailed in Additional file 3. To be included, study populations had to comprise adults (aged 18 or older) living with HIV in high-income countries. We defined high-income countries using the 2019 World Bank classification and Organisation for Economic Co-operation and Development (OECD) country membership [31, 32]. Social determinants focussed on measures of material deprivation and were broadly defined as education, employment, food security, housing, income, poverty (or deprivation), socioeconomic status (or position) and social class. They had to be compared across levels and recorded at either the individual, household, or neighbourhood level. The primary outcomes of interest were HIV treatment-related, specifically medication adherence and viral suppression, measured by VL or CD4 cell counts. We also extracted data of other social factors which may act as confounders, specifically age, gender, sexual orientation, ethnicity and migration status.

\section{Screening, Data Collection and Analysis}

Two authors (VP, AS) screened title and abstracts, followed by full-text, using Covidence [33] and original study authors were contacted by VP to provide any unavailable full-text articles. If the search identified a non-peer-reviewed and peer-reviewed publication for the same study, the most recently published was included. Selected studies were then exported and managed using Excel with a data extraction table initially piloted among 10 studies and subsequently refined. VP extracted data items (Additional file 4) which were cross-checked by EC.

Forest plots were created using Revman 5 [34] for each social determinant and used to present relative effect sizes of comparable associations [adjusted odds ratios $(\mathrm{aOR})$ with 95\% confidence intervals (CIs)]. Data are mainly presented using a narrative synthesis as there were large amounts of heterogeneity between included studies. A random-effects meta-analysis was performed for studies where definitions and measurements across studies were consistent; we present the associated $\mathrm{I}^{2}$ value for heterogeneity (proportion of variation in effect estimates due to heterogeneity rather than chance) [35]. Data presented in forest plots compare poorer social determinants (e.g., unstable housing) to improved determinants (e.g., stable housing).

\section{Quality Assessment}

$\mathrm{VP}$ and BD assess the risk of bias of included studies using the Newcastle-Ottawa scale and an adapted version for cross-sectional studies (Additional file 5) [36, 37]. Studies categorised as 'other' study design, such as secondary data analysis, are assessed using the most appropriate quality assessment tool. We define the most important confounders for studies to adjust for as gender, sexual orientation, age, race/ethnicity and social class, based on the literature [38]. We define adequate follow-up for outcomes based on WHO guidelines of routine VL monitoring of 6 months following ART initiation and measuring ART adherence at 30 days $[39,40]$. No data from 'low quality' studies are included in the meta-analysis; therefore, a sensitivity analysis was not conducted.

\section{Results}

We screened 4031 records, following the removal of duplicates, of which 83 observational studies were eligible (Fig. 1).

Most included studies explored the social determinants of education $(\mathrm{n}=52,62.7 \%)$; followed by housing $(\mathrm{n}=39$, $47.0 \%)$, employment $(\mathrm{n}=33,39.8 \%)$ and income $(\mathrm{n}=33$, $39.8 \%$ ) (Table 1). The studies included a total of $1,445,150$ people living with HIV. Almost three-quarters $(n=61$, $73.5 \%$ ) of the included studies were based in North America. Some studies focussed on specific sub-populations of people living with HIV such as transgender women $(n=5,6.0 \%)$, people who formerly/currently use drugs $(n=3,3.6 \%)$, people in prison $(n=1,1.2 \%)$, migrants $(n=1,1.2 \%)$, people living with HIV and hepatitis $\mathrm{C}(\mathrm{n}=1,1.2 \%)$, homeless/ marginally housed individuals $(\mathrm{n}=1,1.2 \%)$ as well as individuals who hold multiple identities; for instance, being in 


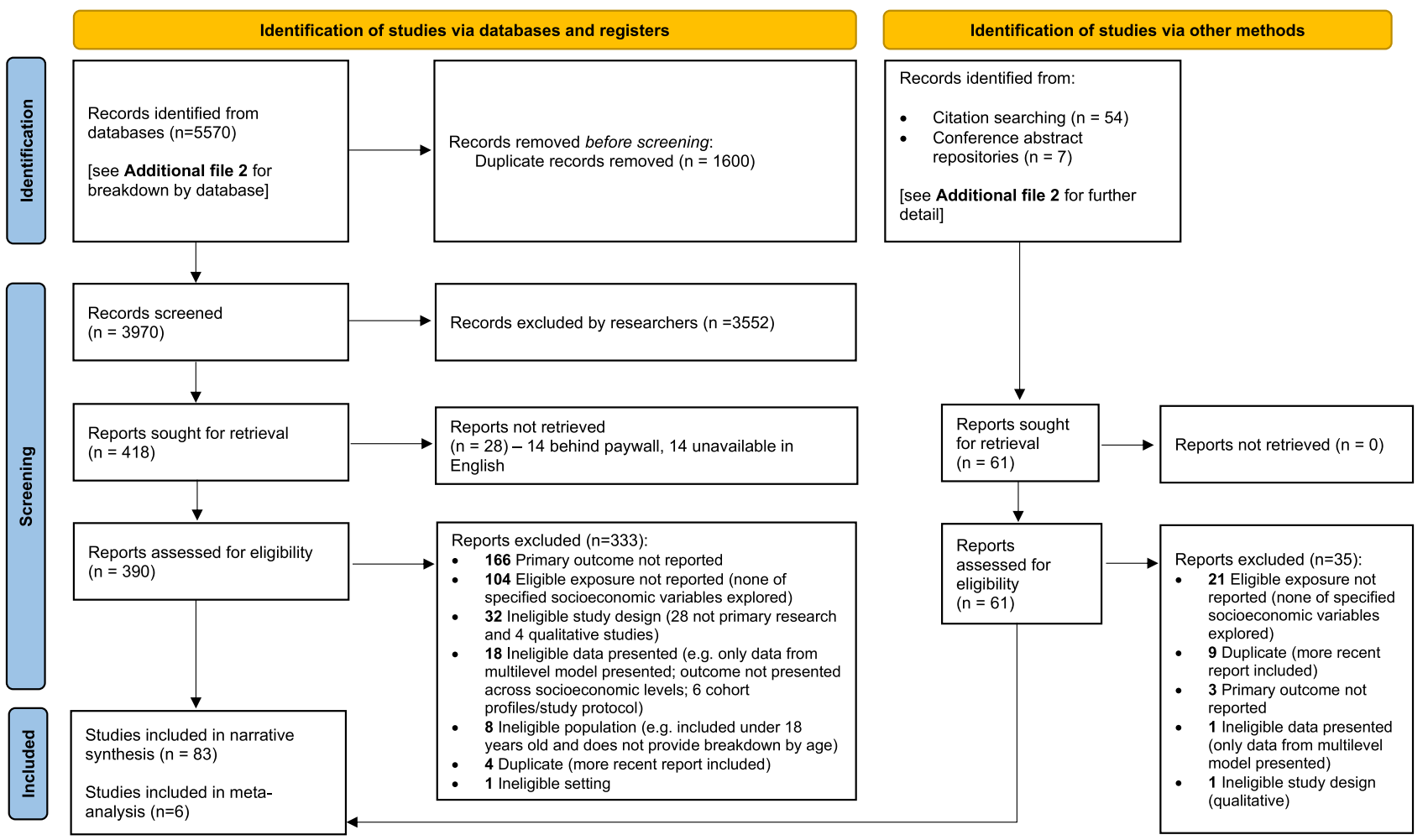

Fig. 1 PRISMA 2020 flow diagram. Adapted from Page et al. [29]

prison and homeless $(\mathrm{n}=1,1.2 \%)$ or being socioeconomically disadvantaged and using drugs $(n=1,1.2 \%)$.

We identified 38 studies that explored the association between social determinants and virological suppression (or non-suppression); 35 that investigated adherence (or nonadherence) to ART including combination ART (cART) and highly active ART (HAART); and 10 that explored both primary outcomes. Study characteristics are detailed in Table 2.

Most studies measuring viral suppression predominantly recorded VL, although some also reported the immunological response of CD4 cell count. The VL thresholds to meet viral suppression varied across studies from 20 to 400 VL copies/mL or defined as 'detectable' or 'undetectable'. Adherence had more varied measurements; some studies asked how often participants had missed medication in a specific time frame or used medication event monitoring systems (MEMS) to record the number of times a pill cap was opened which was sometimes also verified by an unannounced pill count by phone. One study [41] used an index of the "number of days out of medication" (MED-OUT) using pharmacy-refill based measures.

Social determinants primarily focussed on measures of material deprivation. This included education (e.g., level, attainment, student status); employment (e.g., status, grade, type); housing (e.g., status, stability, homelessness, living situation, condition, ownership); measures of food security; income (e.g., annual household, financial stability, receiving benefits, financial hardship/concerns, economic situation); socioeconomic status/position (individual/neighbourhood); and measures of deprivation and social class.

We present data under the following headings: education, employment, housing, and material deprivation (which includes measures of deprivation, food security, income, and socioeconomic status/position). For some studies, we present the inverse of the data reported in the original manuscript as we were interested in the outcomes of virological suppression and ART adherence. A full summary of findings, including the confounders adjusted for and reference categories, is provided in Additional file 6.

\section{Education}

Education was typically defined by the highest educational level of attainment; from primary school in the UK (or elementary school in the US) to university qualifications.

Of 83 studies, 52 focussed on education with nine studies reporting a significant adjusted association with virological suppression [43, 84, 88, 97, 103, 106, 107, 116, 119]; four reported negative associations (lower education) and five positive (higher education). Overall, people who had lower educational levels were less likely to be virologically suppressed (Fig. 2a; Additional file 6) than individuals who had 
Table 1 Summary of key characteristics of included studies

\begin{tabular}{|c|c|}
\hline Characteristic & Total studies (\%) \\
\hline \multicolumn{2}{|l|}{ Publication type } \\
\hline Peer-reviewed (e.g., journal article, short/brief report, short/concise communication) & $77(92.8)$ \\
\hline Not peer-reviewed (e.g., conference abstract, editorial letter, thesis) & $6(7.2)$ \\
\hline \multicolumn{2}{|l|}{ Setting } \\
\hline North America & $61(73.5)$ \\
\hline Europe & $20(24.1)$ \\
\hline Asia & $1(1.2)$ \\
\hline Australia & $1(1.2)$ \\
\hline \multicolumn{2}{|l|}{ Study design } \\
\hline Cohort/longitudinal & $31(37.3)$ \\
\hline Cross-sectional $^{\mathrm{b}}$ & $30(36.1)$ \\
\hline Other $^{c}$ & $22(26.5)$ \\
\hline \multicolumn{2}{|l|}{ Social determinants ${ }^{\mathrm{a}}$} \\
\hline Education & $52(62.7)$ \\
\hline Employment & $33(39.8)$ \\
\hline Food security & $7(8.4)$ \\
\hline Housing & $39(47.0)$ \\
\hline Income & $33(39.8)$ \\
\hline Poverty/deprivation & $9(10.8)$ \\
\hline Socioeconomic status/position & $4(4.8)$ \\
\hline Social class & $1(1.2)$ \\
\hline \multicolumn{2}{|l|}{ Primary outcome(s) } \\
\hline Viral (non-)suppression ${ }^{\mathrm{d}}$ & $38(45.8)$ \\
\hline Medication (non-)adherence ${ }^{\mathrm{e}}$ & $35(42.2)$ \\
\hline Both & $10(12.0)$ \\
\hline \multicolumn{2}{|l|}{ Secondary outcome $(\mathrm{s})^{\mathrm{a}}$} \\
\hline Diagnosis-related & $1(1.2)$ \\
\hline Medication-related (e.g., initiation, use, coverage, response) & $8(9.6)$ \\
\hline HIV care-related (e.g., engagement, retention, missed visits) & $13(15.7)$ \\
\hline
\end{tabular}

${ }^{a}$ More than 1 option possible

${ }^{b}$ Includes cross-sectional surveys of cohort studies

${ }^{\mathrm{c}}$ Mixed methods (observational data extracted), programme evaluations, needs assessment, cross-sectional surveys/analysis of cohort studies and chart/record/baseline intervention reviews

${ }^{\mathrm{d}} \mathrm{CD} 4$ cell count, HIV viral load

${ }^{\mathrm{e}} \mathrm{ART}, \mathrm{cART}, \mathrm{HAART}$ higher educational attainment after adjusting for confounders $[53,88,106]$. For instance, in a cohort of 1246 people living with HIV attending healthcare in France, D'Almeida et al. [106] found individuals whose highest educational attainment was elementary school were $60 \%$ less likely (aOR $0.40 ; 95 \%$ CI $0.18,0.90$ ) to have a VL $<50$ copies $/ \mathrm{mL}$, compared to those with more than 2 years of a university degree. Shacham et al.[88] found that individuals presenting at an urban HIV clinic in the US, with a high school diploma or less were over 2-times more likely (aOR 2.32; 95\% CI 1.08, $5.00)$ to be virologically non-suppressed; this study used a higher threshold (VL $<400$ copies/mL).

The direction of the association between education and medication adherence was less clear. Four studies reported a significant adjusted negative association with medication adherence and lower educational attainment [57, 93, 103, 118]; one [93] also reported positive associations among some sub-groups (Fig. 2b; Additional file 6). Sunil and McGehee [93] found different patterns across educational levels when stratifying by race/ethnicity. White Americans $(\mathrm{n}=992)$ who had completed high school, some College or had an undergraduate qualification were $30 \%$ (aOR 1.30; 95\% CI 1.24, 1.37), 41\% (aOR 1.41; 95\% CI 1.34, 1.48) and $58 \%$ (aOR 1.58; 95\% CI 1.51, 1.66) more likely, respectively, to be adherent to ART compared to individuals who completed some high school only [93]. The same general trend was seen for African American participants $(n=581)$ : individuals who completed high school and some College 


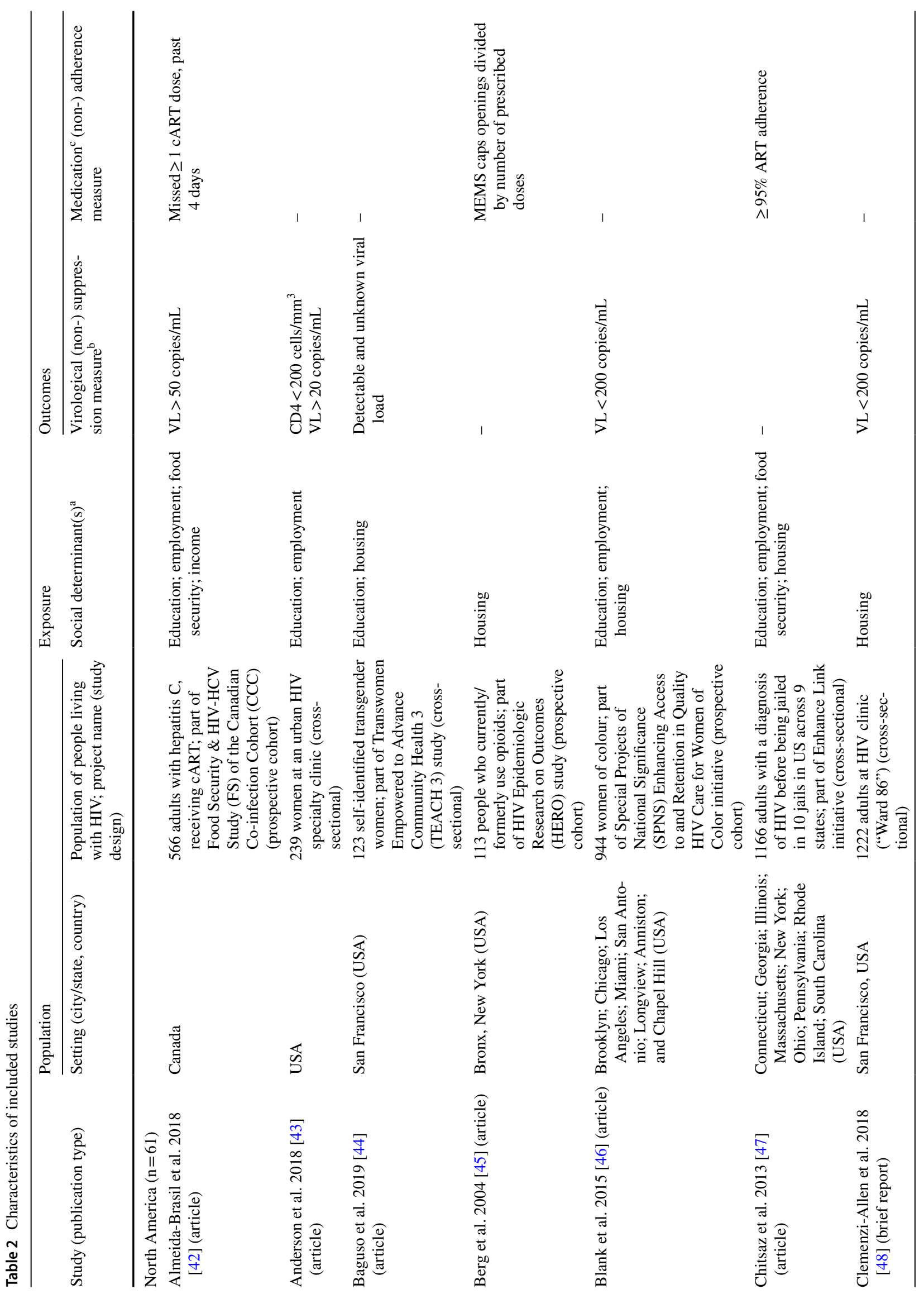




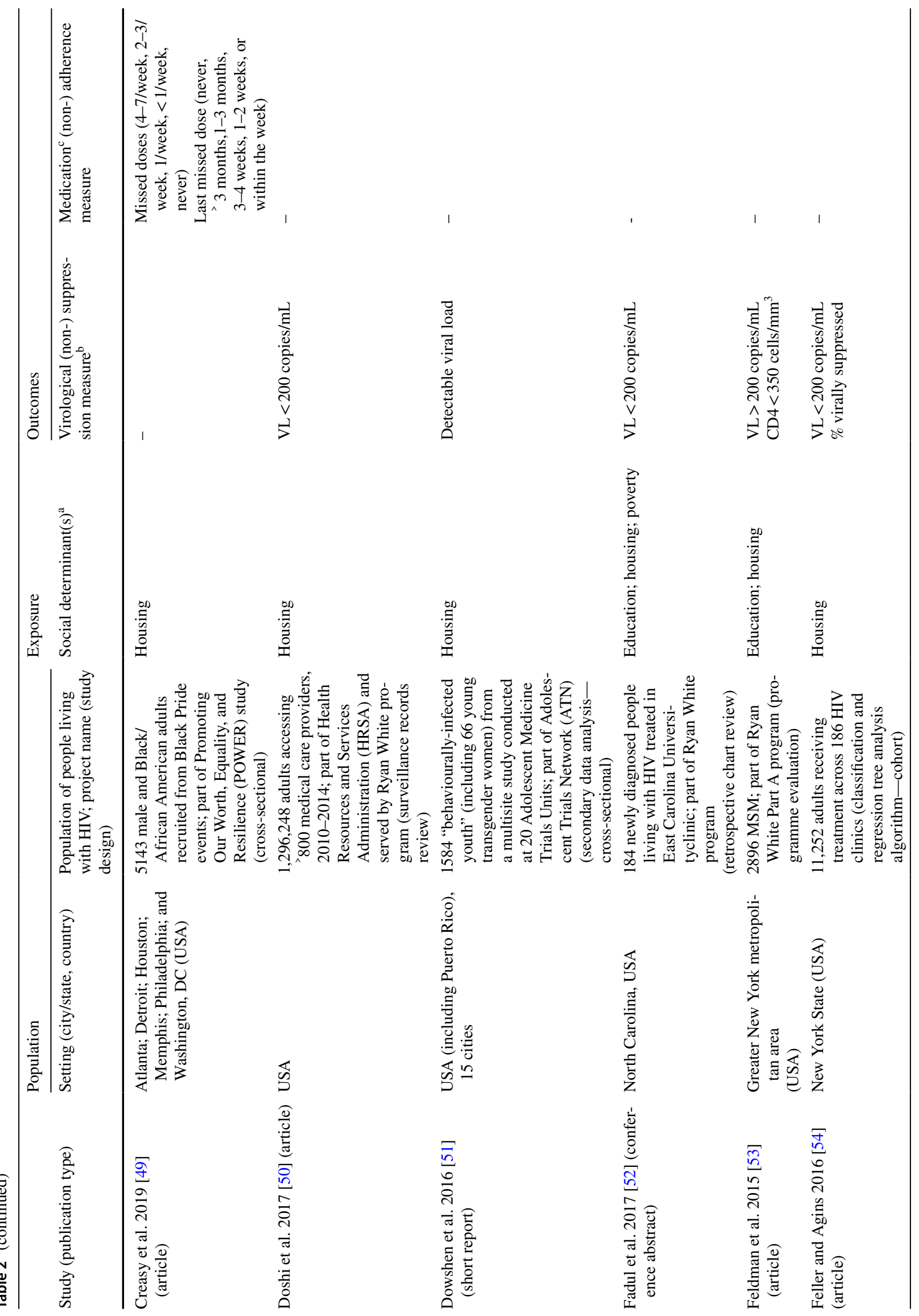




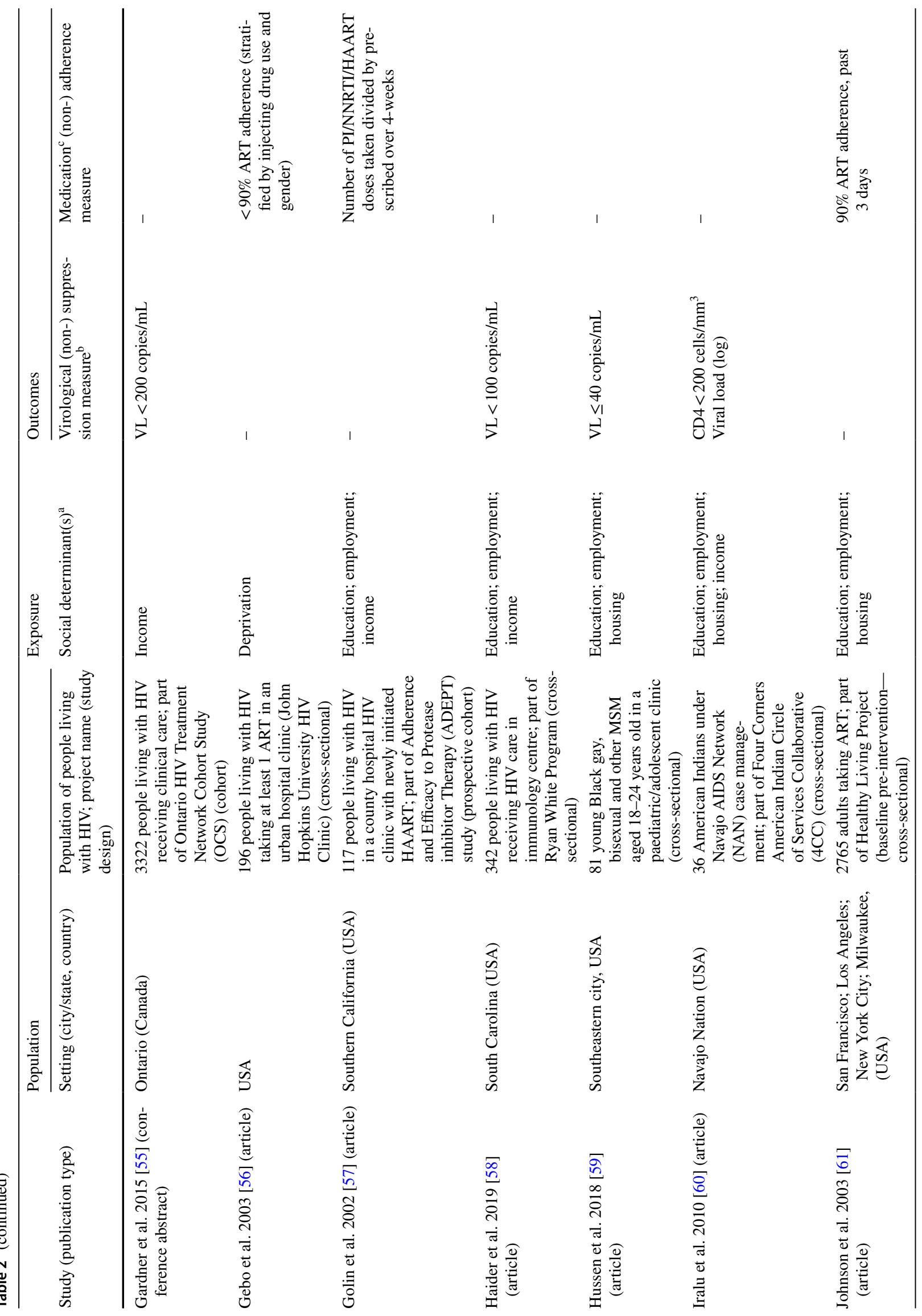




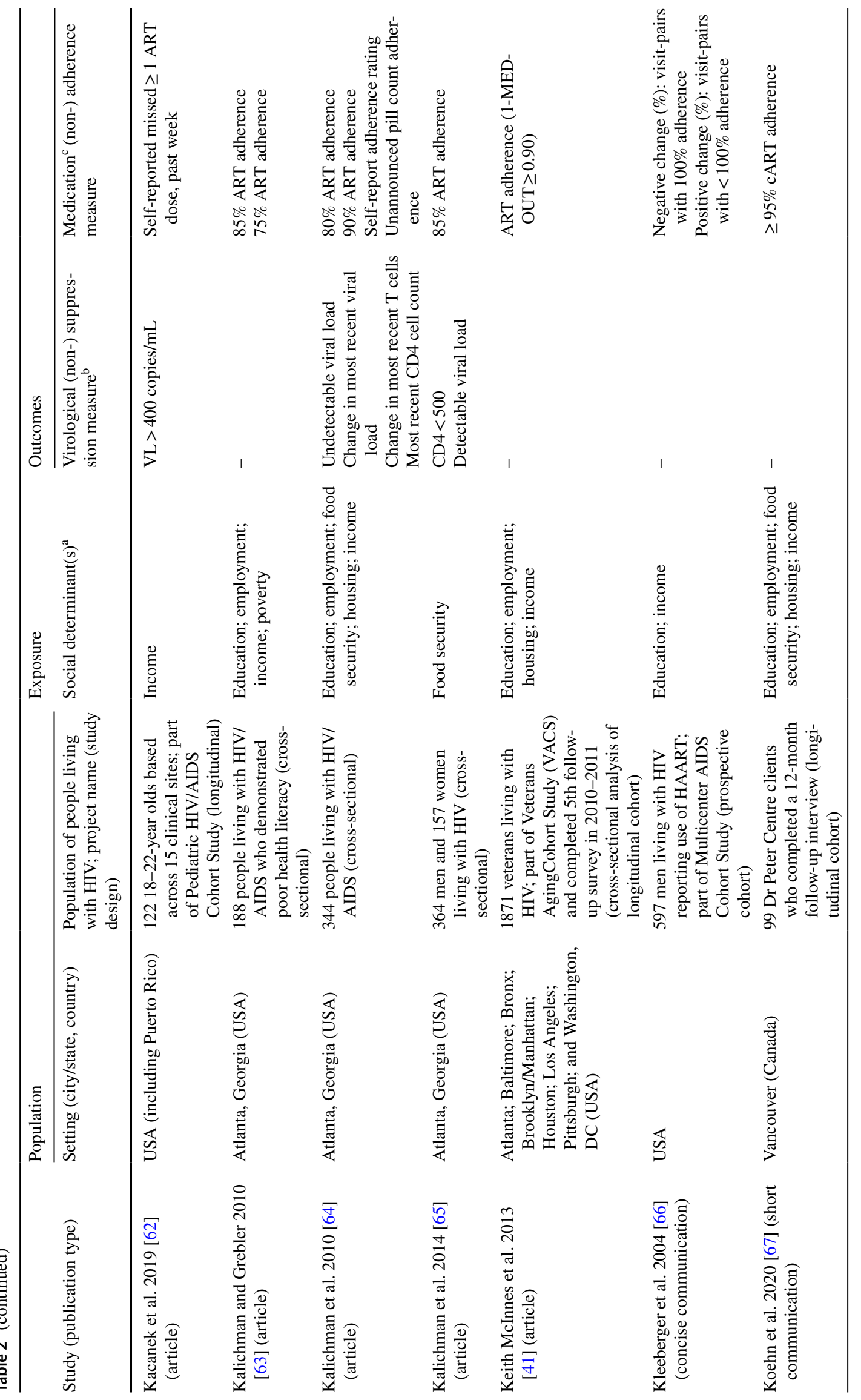




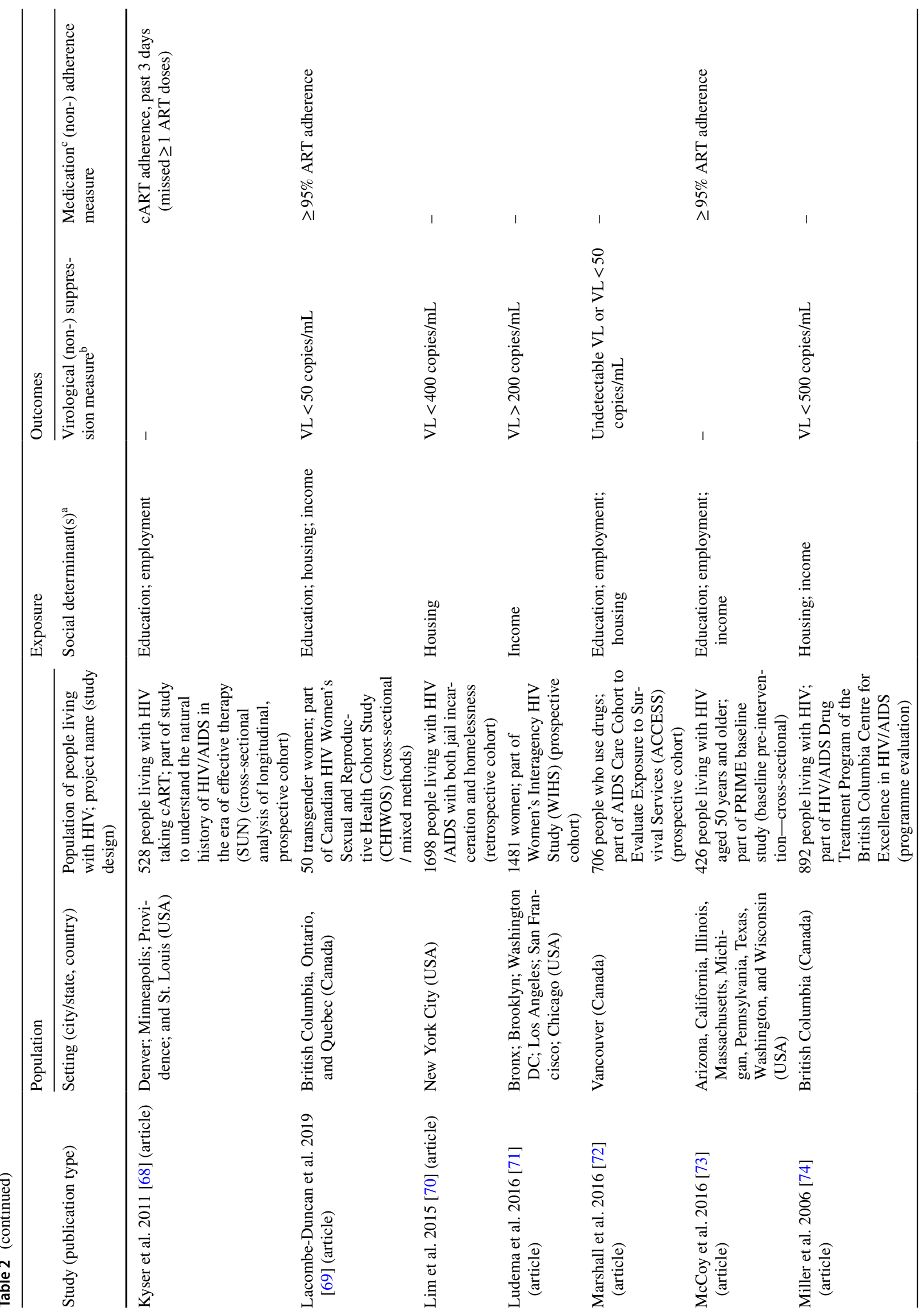




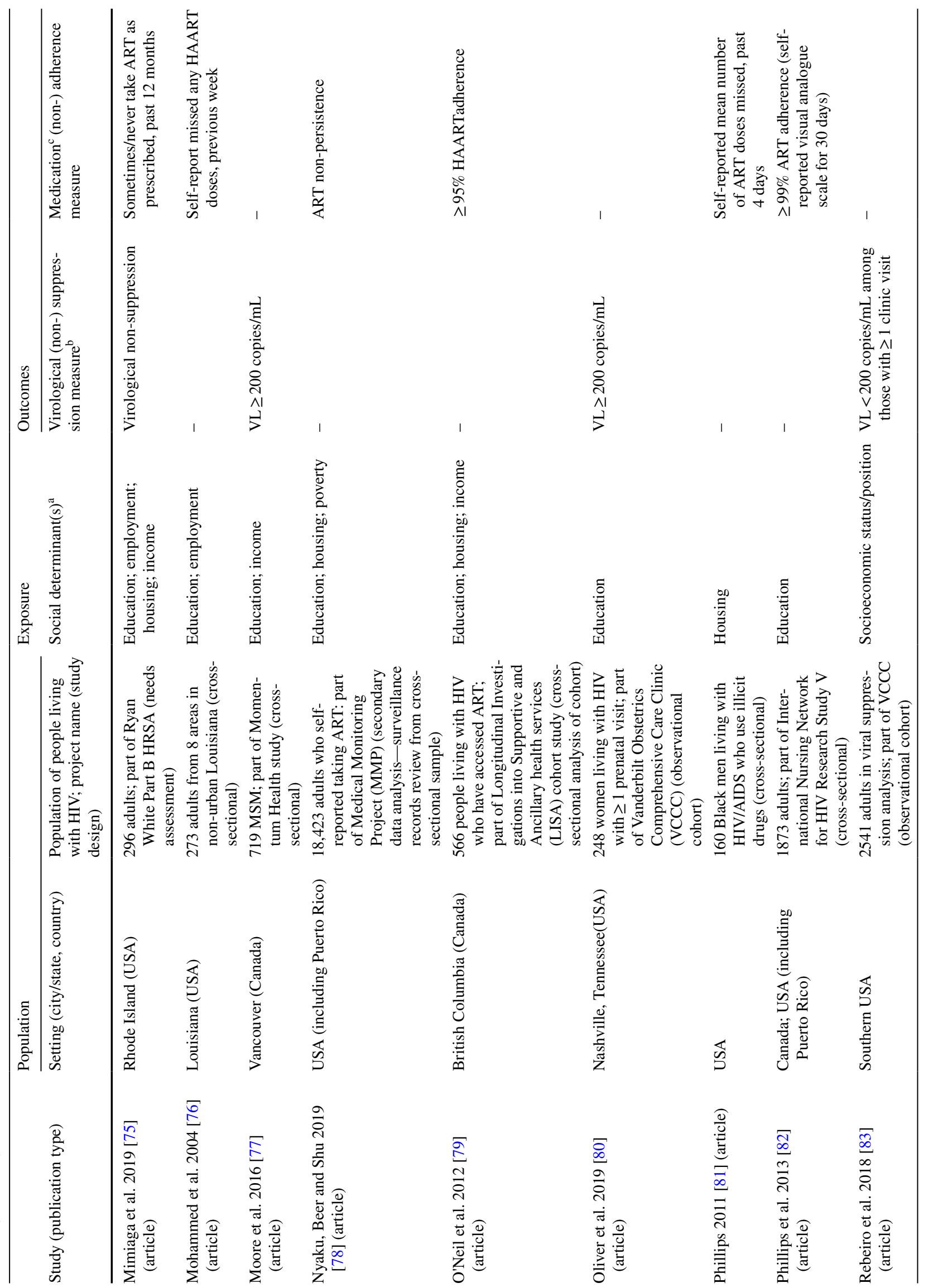




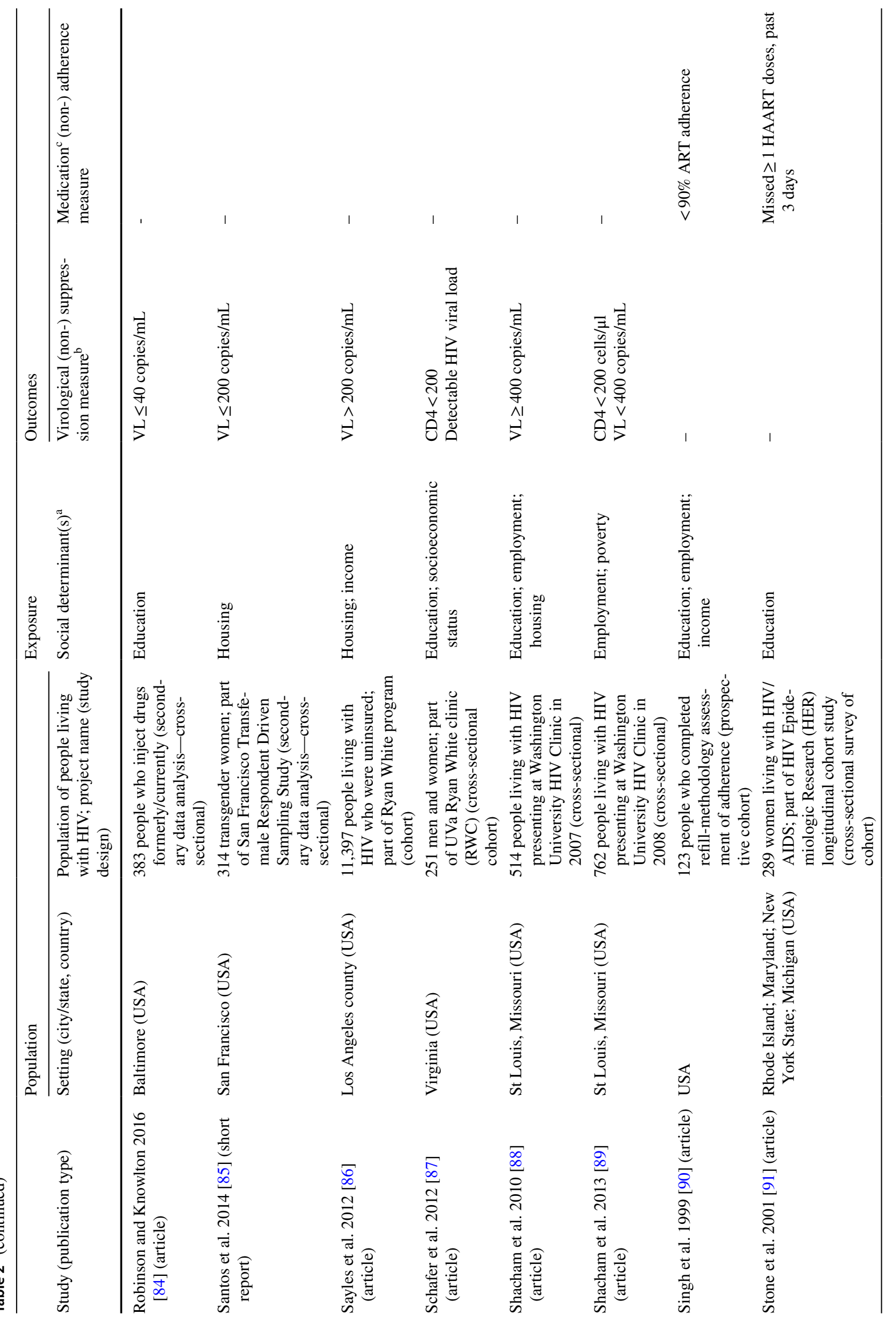




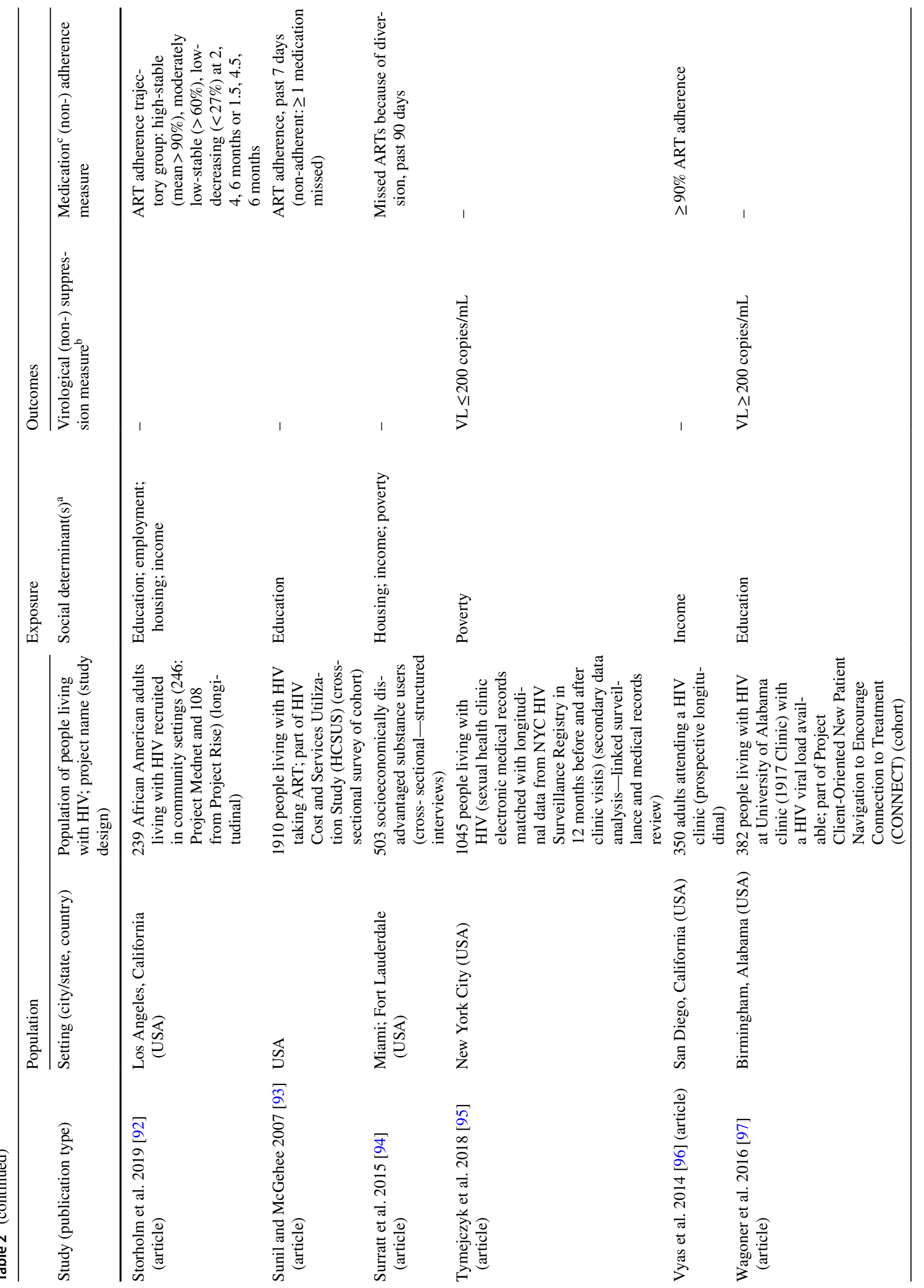




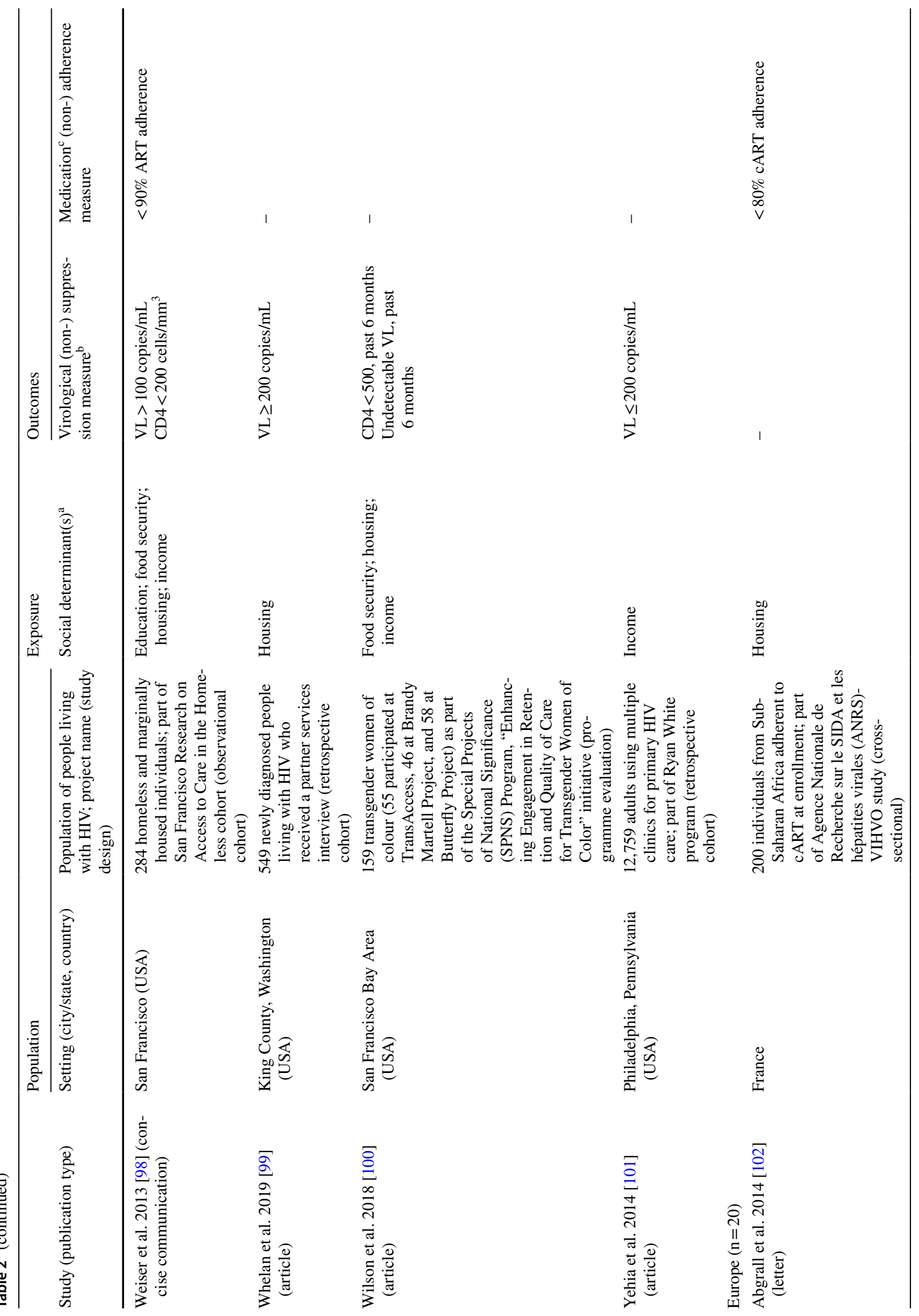




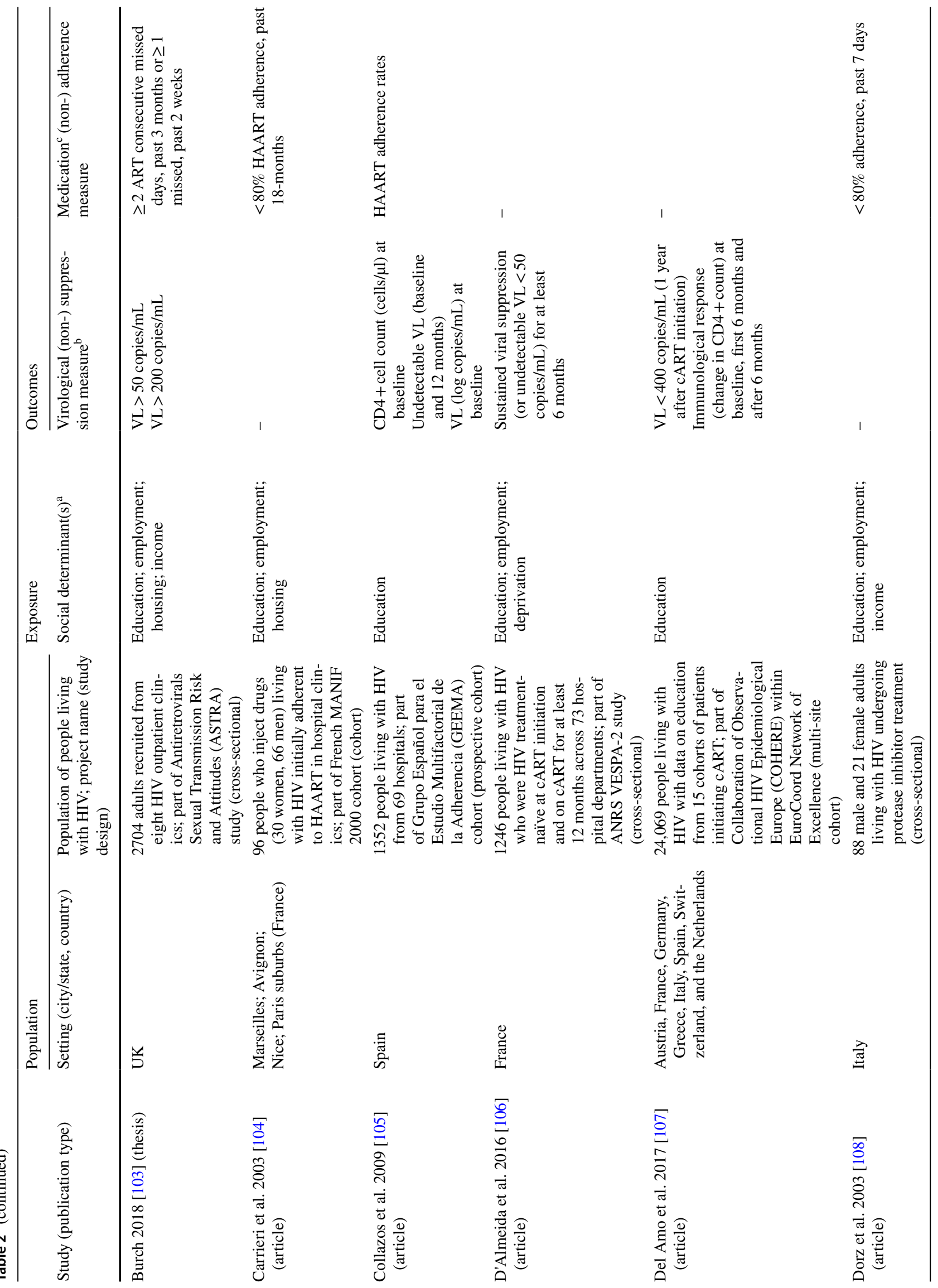




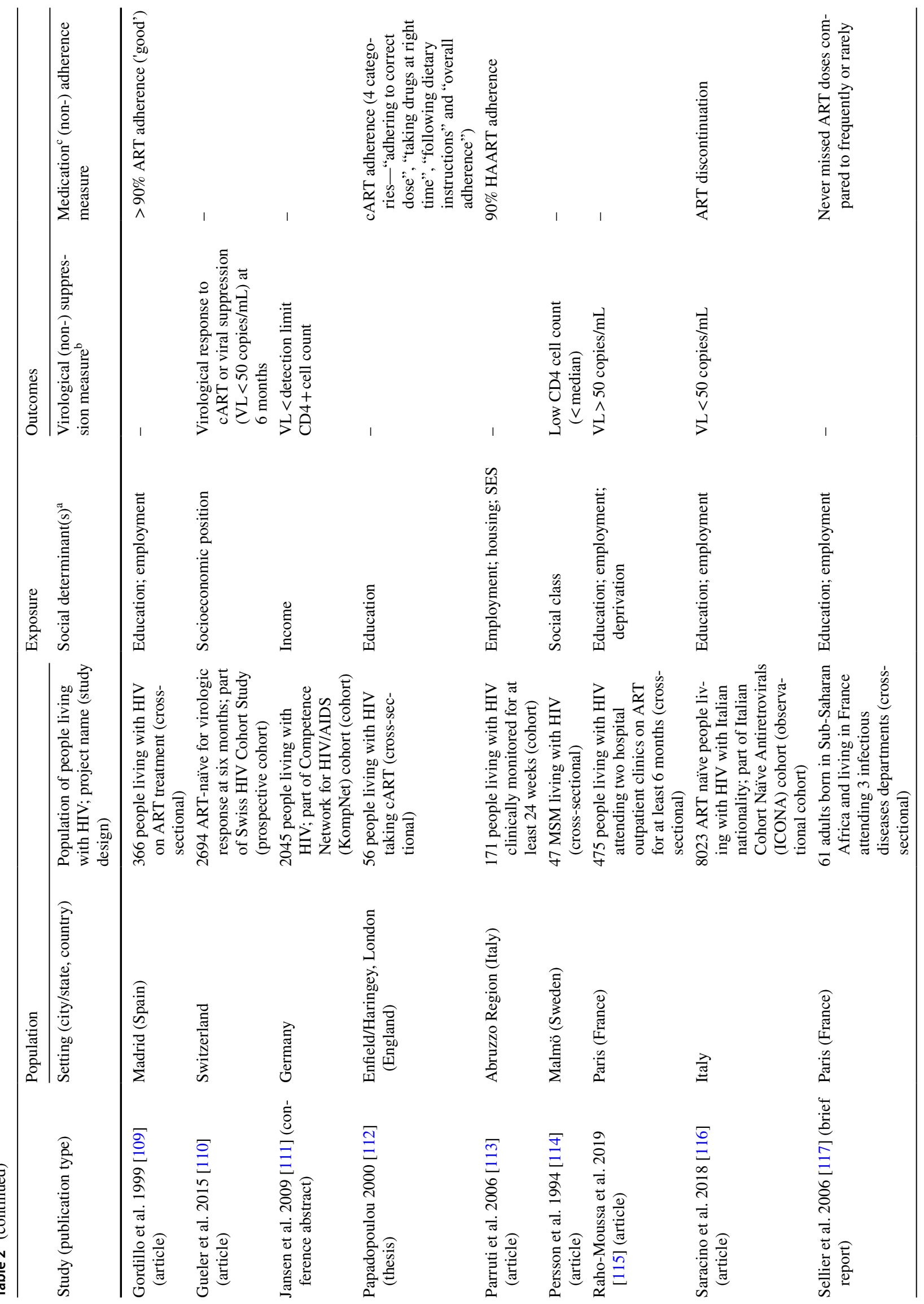




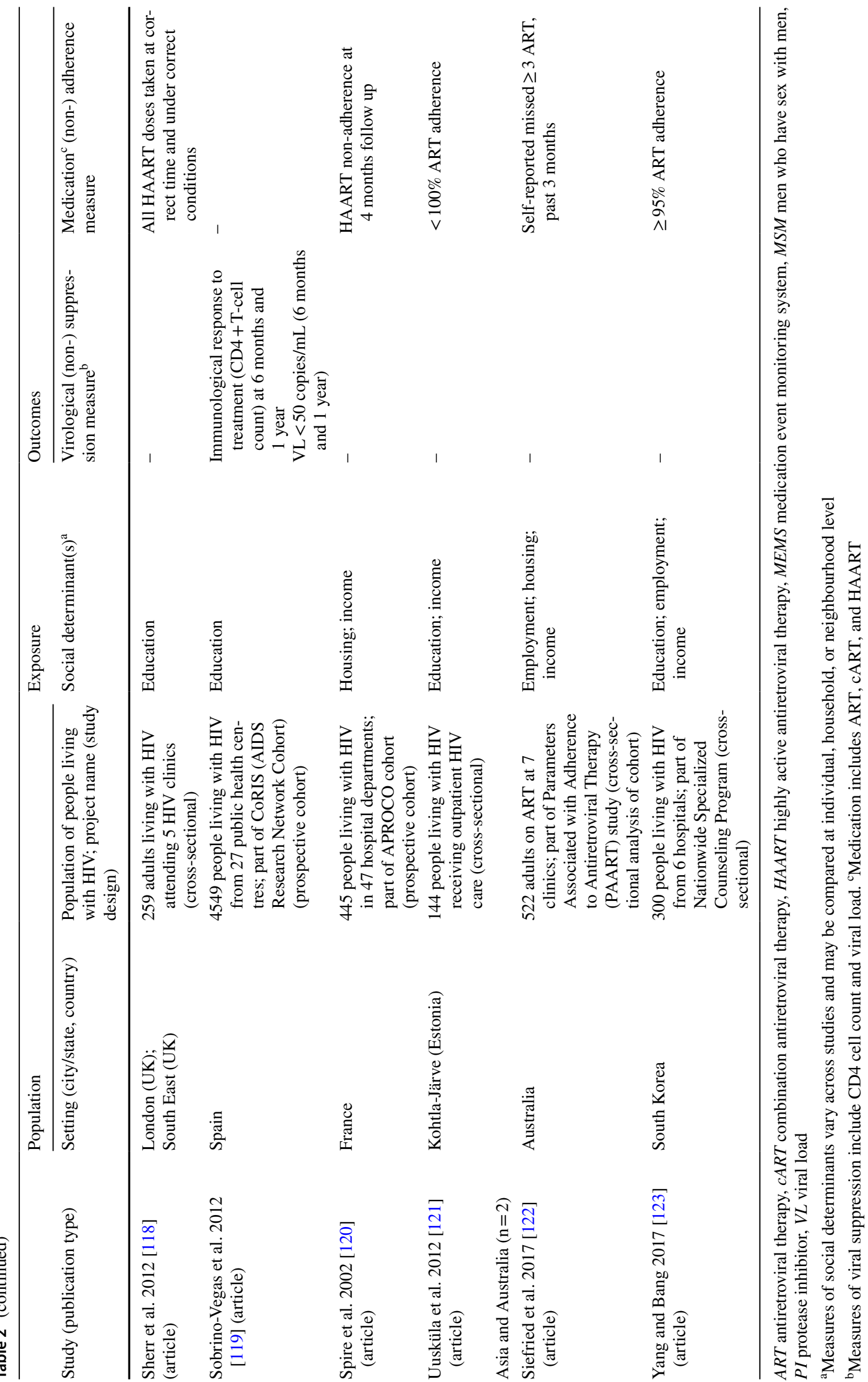




\section{(a) Educational attainment and virological suppression}

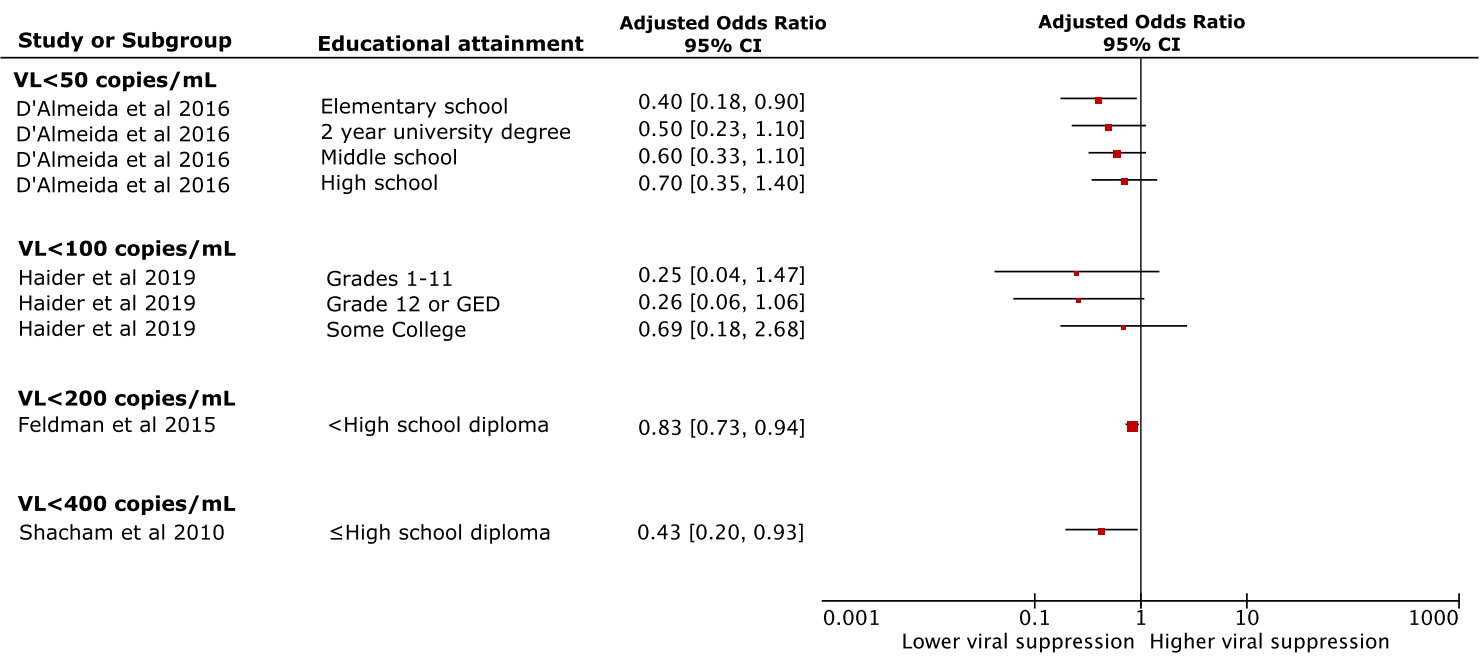

\section{(b) Educational attainment and medication adherence}

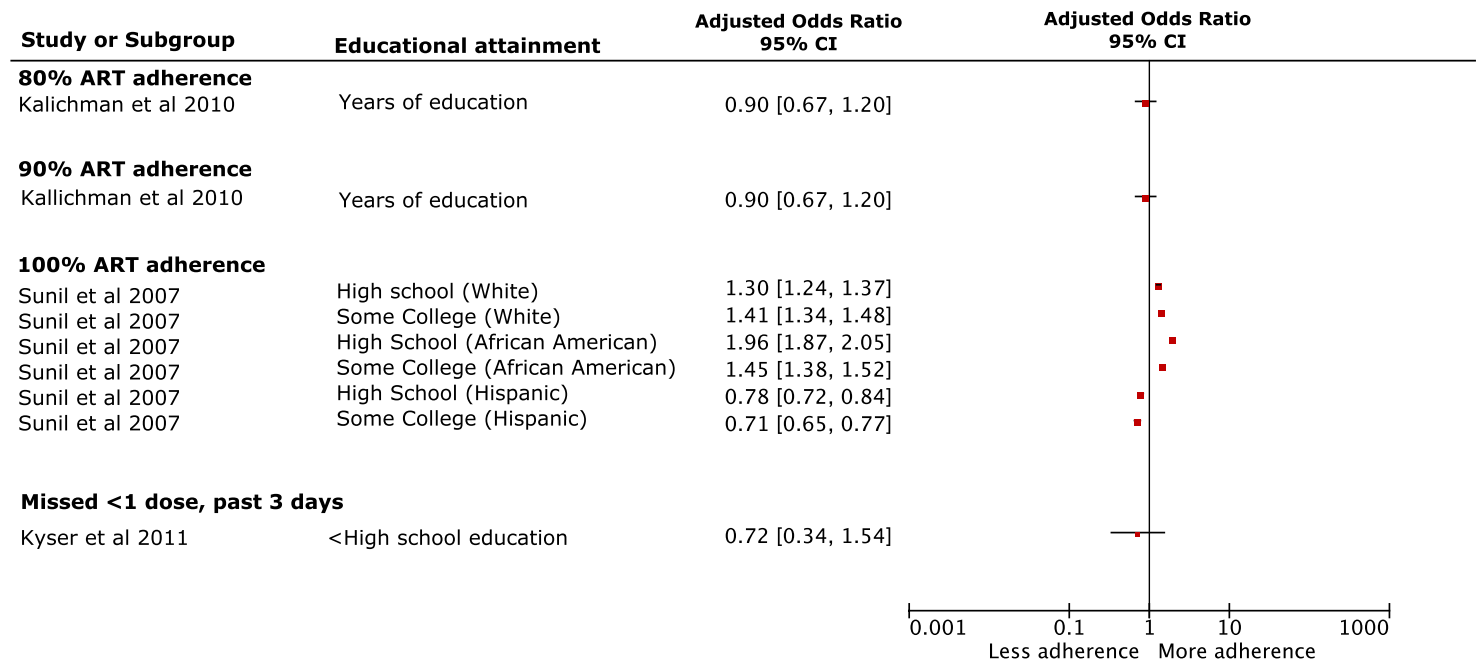

Fig. 2 Forest plots of likelihood (aOR) of a virological suppression and $\mathbf{b}$ medication adherence among people living with HIV with low, compared to high, educational attainment after adjusting for sociode-

were $96 \%$ (aOR 1.96; 95\% CI 1.87, 2.05) and $45 \%$ (aOR $1.45 ; 95 \%$ CI $1.38,1.52$ ) more likely to be adherent to ART than those who only completed some high school, however those with an undergraduate qualification were $12 \%$ less likely (aOR $0.88 ; 95 \%$ CI $0.82,0.95$ ) to be adherent [93]. For Hispanic American participants $(n=272)$, the direction of association was less sequential; individuals who had completed high school or some College were $22 \%$ (aOR 0.78; $95 \%$ CI $0.72,0.84$ ) and $29 \%$ (aOR 0.71; 95\% CI 0.66, 0.77) less likely, respectively, to be adherent whereas university graduates were $40 \%$ more likely (aOR 1.40; 95\% CI 1.27, mographic factors. ART antiretroviral therapy, GED general educational diploma, $V L$ viral load

$1.55)$ to be adherent compared to those who only completed some high school [93].

\section{Employment}

Employment was defined either by status, occupation type or whether work was paid.

Of 83 studies, 33 looked at employment with only three studies reporting a significant association with virological suppression after adjustment for confounders [58, 103, 116]; two associations were negative (those unemployed), one was 
positive (those employed) (Fig. 3a; Additional file 6). Overall, there was an inconsistent association between employment and virological suppression. For instance, D'Almeida et al.[106] reported no difference in viral suppression between people living with HIV of a lower employment grade or unemployed working status compared with executive occupational grades or employed. However, Saracino et al. 2018 [116] found that unemployed people living with HIV had lower rates (adjusted Hazard Ratio [aHR] 0.87; 95\% CI 0.79, 0.96) of virological suppression, compared to full-time workers. Similarly, Burch [103] reported that the prevalence of virological non-suppression $(\mathrm{VL}>50$ copies $/ \mathrm{mL}$ ) was almost 2-times greater among the unemployed, compared to employed (adjusted Prevalence Ratio [aPR] 1.98; 95\% CI 1.51, 2.61).

Similarly, the association between medication adherence and employment varied. Four studies reported a significant adjusted association with medication adherence
$[47,68,103,116]$; three reported a negative association (those unemployed) and one a positive association (those employed) (Fig. 3b; Additional file 6). Saracino et al.[116] found unemployed people living with HIV were more at risk of discontinuing ART (aHR 1.18; 95\% CI 1.04, 1.34) and when they looked at specific job types, "housewives" were found to be less at risk of ART discontinuation (aHR 0.73; 95\% CI 0.59, 0.90), after adjusting for CD4 count, VL, pregnancy status and smoking. Kyser et al.[68] reported that people living with HIV who were unemployed or looking for work were over 2-times more likely (aOR 2.03; 95\% CI 1.14, 3.61 ) to report having missed cART doses in the past 3 days.

\section{Housing}

Some studies described housing as the physical environment; some grouped individuals into categories of 'unstable'

\section{(a) Employment grade/status and virological suppression}

\begin{tabular}{|c|c|c|c|c|}
\hline Study or Subgroup & Employment grade/status & $\begin{array}{c}\text { Adjusted Odds Ratio } \\
95 \% \mathrm{CI}\end{array}$ & $\begin{array}{c}\text { Adjusted Odds Ratio } \\
95 \% \mathrm{CI}\end{array}$ & \\
\hline \multicolumn{5}{|l|}{ VL $<50$ copies $/ \mathrm{mL}$} \\
\hline D'Almeida et al 2016 & Unemployed & $0.60[0.36,1.00]$ & & \\
\hline D'Almeida et al 2016 & Tradesperson & $0.70[0.31,1.60]$ & 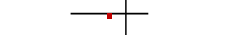 & \\
\hline D'Almeida et al 2016 & Retiree & $0.80[0.38,1.70]$ & - & \\
\hline D'Almeida et al 2016 & On disability & $0.90[0.45,1.80]$ & - & \\
\hline D'Almeida et al 2016 & Inactive employment & $1.00[0.45,2.20]$ & 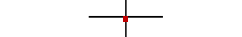 & \\
\hline D'Almeida et al 2016 & Clerk & $1.10[0.61,2.00]$ & - & \\
\hline D'Almeida et al 2016 & Other occupational grade & $1.10[0.18,6.60]$ & & \\
\hline D'Almeida et al 2016 & Manual worker & $1.50[0.78,2.90]$ & 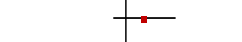 & \\
\hline \multicolumn{5}{|l|}{ VL $<200$ copies/mL } \\
\hline Blank et al 2015 & Disabled employment status & $0.70[0.33,1.45]$ & - & \\
\hline Blank et al 2015 & Not working/other employment status & $0.84[0.41,1.69]$ & - & \\
\hline \multicolumn{5}{|l|}{$\mathrm{VL}<400$ copies $/ \mathrm{mL}$} \\
\hline \multirow[t]{2}{*}{ Shacham et al 2013} & $\% \geq$ median unemployed & $0.84[0.58,1.21]$ & $\rightarrow$ & \\
\hline & & 0.001 & 0.1 & 1000 \\
\hline
\end{tabular}

\section{(b) Employment grade/status and medication adherence}

\begin{tabular}{|c|c|c|c|c|c|}
\hline Study or Subgroup & Employment grade/status & $\begin{array}{c}\text { Adjusted Odds Ratio } \\
95 \% \text { CI } \\
\end{array}$ & $\begin{array}{r}\text { Adjusted O } \\
95 \% \\
\end{array}$ & $\begin{array}{l}\text { Odds Ratio } \\
\% \text { CI }\end{array}$ & \\
\hline $\begin{array}{l}\text { 90\% adherence } \\
\text { Kalichman et al } 2010\end{array}$ & Unemployment & $2.30[0.83,6.40]$ & & & \\
\hline *Adjusted for different confounders & & 0.001 Les & $\begin{array}{cc}0.1 & 1 \\
\text { adherence }\end{array}$ & $10 \begin{array}{c}10 \\
\text { More adher }\end{array}$ & 1000 \\
\hline
\end{tabular}

Fig. 3 Forest plots of likelihood (aOR) of $\mathbf{a}$ virological suppression and $\mathbf{b}$ medication adherence among people living with HIV with lower employment grade or unemployed status, compared to high, after adjusting for sociodemographic factors. $V L$ viral load 
and 'stable' housing; some used time of residence and others used home ownership. We grouped studies which explored the association between people living with HIV in unstable compared to stable housing and differing VL thresholds. Housing 'stability' was either explicitly described by the authors or was defined in relation to the type of housing (e.g., living in subsidised housing or in a shelter).

Of 83 studies, 39 looked at housing with eight studies reporting a significant adjusted association with virological suppression, all of which were a negative association, i.e., more unstable housing was associated with lower viral suppression [44, 48, 50, 53, 72, 85, 98, 103] (Fig. 4a; Additional file 6). As measurements and definitions of housing status and virological suppression were consistent, we conducted a random-effects meta-analysis of this determinant and outcome. Most included studies in the meta-analysis used a VL threshold <200 copies/mL [46, 48, 53, 85, 86] however, one used $<100$ copies/mL [98]. The pooled aOR of studies that used a VL threshold of $<200$ copies/mL was $0.48(95 \%$ CI $0.33,0.70)$ with high heterogeneity between the studies $\left(\mathrm{I}^{2}=90 \%\right)$. All but 5 reported subgroups found unstable housing to be significantly associated with lower

\section{(a) Housing status and virological suppression}

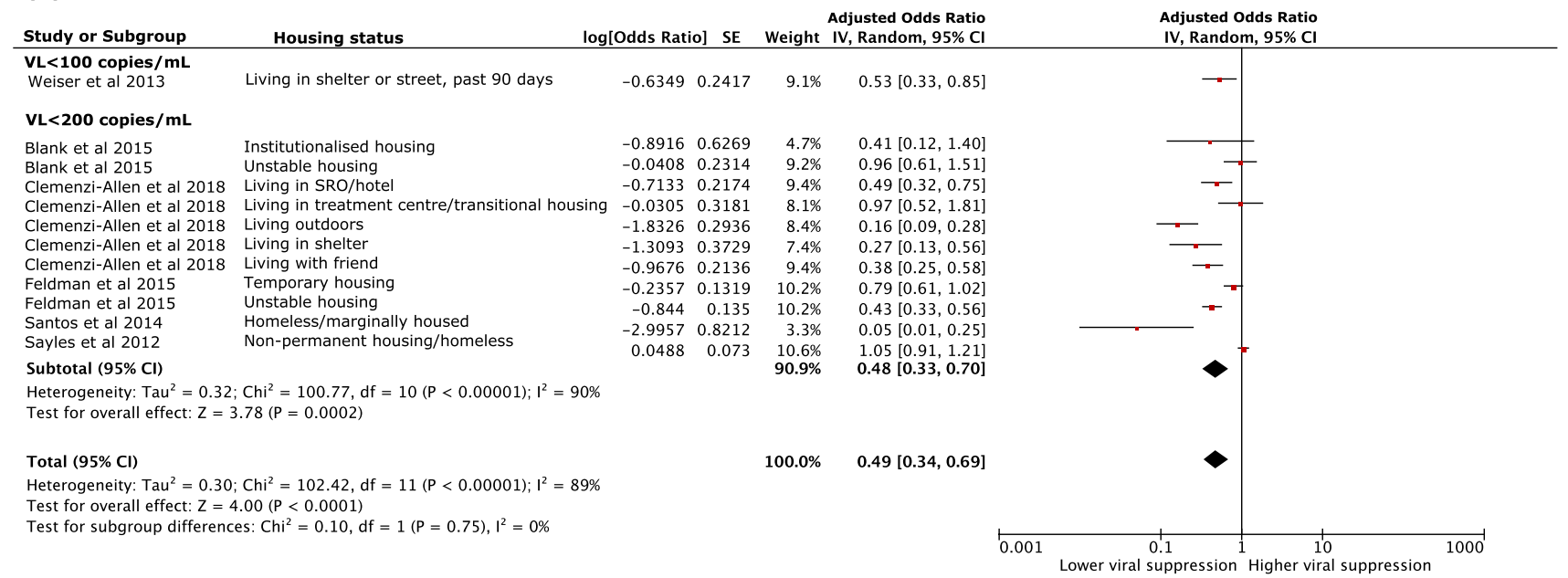

\section{(b) Housing status and medication adherence}

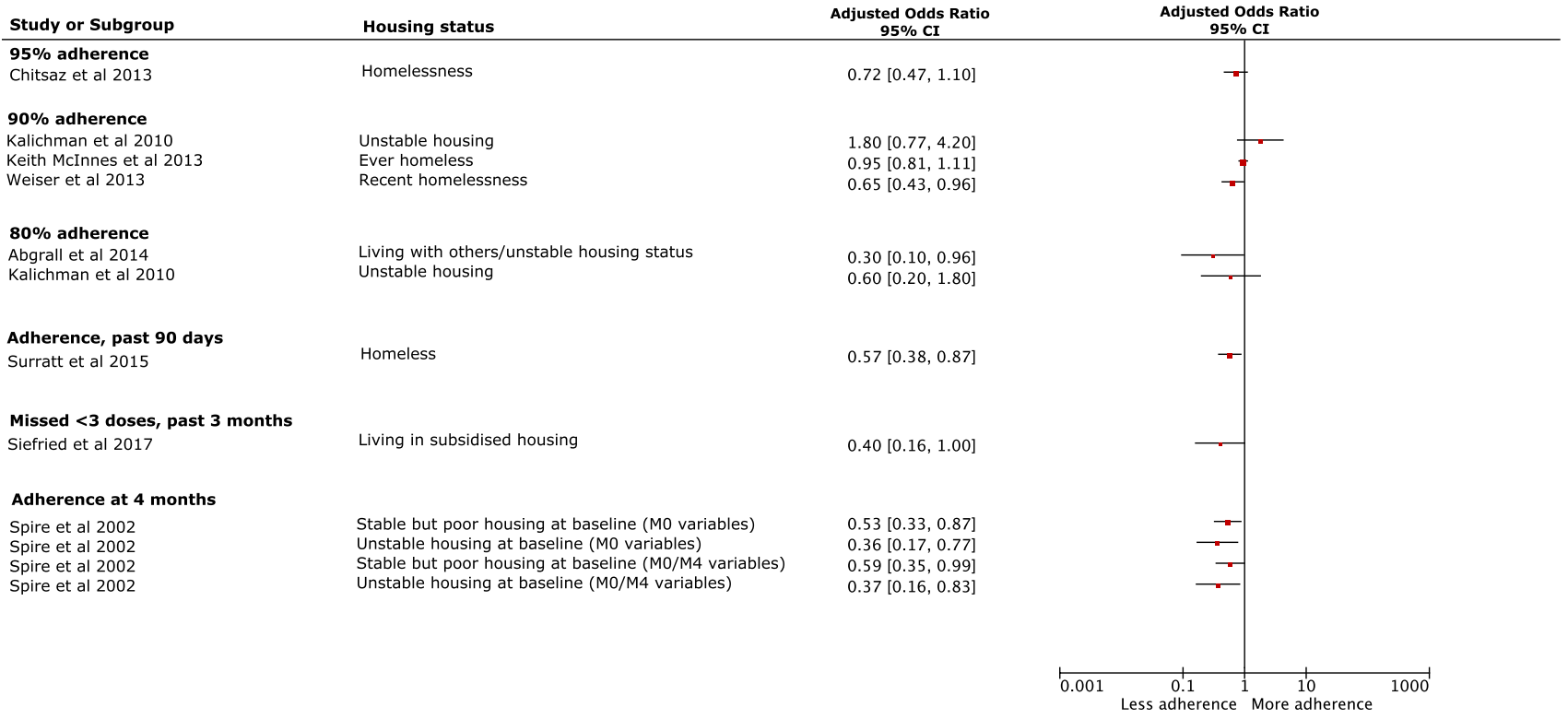

Fig. 4 Forest plots of likelihood (aOR) of a virological suppression and $\mathbf{b}$ medication adherence among people living with HIV living in unstable, compared to stable, housing after adjusting for sociodemo- graphic factors. A meta-analysis is presented for virological suppression. MO month 0, M4 month 4, SRO single room occupancy, $V L$ viral load 
viral suppression with the strongest relative effect reported by Santos et al. [85]. Santos et al. [85] found that homeless or marginally, compared to stably, housed transgender women living with HIV were 95\% less likely (aOR 0.05; 95\% CI $0.01,0.25$ ) to be virally suppressed after adjusting for social factors including age and race/ethnicity. Overall, the pooled aOR was 0.49 (95\% CI $0.34,0.69)$ with the random-effects model for meta-analysis displaying considerable heterogeneity across studies $\left(\mathrm{I}^{2}=89 \%\right)$ [35].

Nine of 39 studies looking at housing found a significant adjusted association with medication adherence [45, 81, 94, $98,102,103,113,120,122]$; eight reported a negative association (unstable housing or homelessness) and one positive (long-term housing) (Fig. 4b; Additional file 6). Individuals living in unstable housing across a range of settings, including subsidised housing [122], living with others [102], being recently homeless $[81,94,98,113]$ or renting [103], were at greater risk of experiencing medication adherence failure, compared to those with more stable living situations. Spire et al. [120] looked at housing quality and found individuals living in stable, but poor housing or unstable housing at baseline have a greater likelihood of being non-adherent to HAART following 4-months of follow-up after adjusting for age, marital status and other intermediary determinants [120].

\section{Other Measures of Material Deprivation}

Some studies grouped social determinants to report one overall deprivation measure; for instance, Kalichman and Grebler [63] grouped social determinants of housing, food and financial security as "poverty-related experiences" or "stressors." We present comparable aORs exploring the association between measures of material deprivation, including food security, with virological suppression and medication adherence (Fig. 5; Additional file 6) and a narrative synthesis provided for each factor. Of 83 studies, 53 explored a measure of deprivation: specifically, food security $(n=7)$, poverty/deprivation explicitly $(n=9)$, income $(\mathrm{n}=33)$ and socioeconomic status/position $(\mathrm{n}=4)$.

\section{Food Security}

Food security is measured at the individual level using specific measurement tools such as the Household Food Security Survey Module (HFSSM). Food security was sometimes reported as a combined measure with income. One of seven food security studies reported a significant negative adjusted association with viral suppression [98]. Weiser et al.[98] found that individuals who reported any food insecurity were $29 \%$ more likely to be virologically non-suppressed (aOR 1.29; 95\% CI 1.04, 1.61); however, the same study [98] found no difference in virological suppression among food insecure individuals after adjusting for adherence. Six studies investigating food security and adherence found a significant negative adjusted association $[42,56,64,65$, 67, 98]. For instance, Almeida-Brasil et al.[42] examined a cohort of adults in Canada living with HIV and hepatitis C and established that there was no difference in virological suppression (VL $>50$ copies $/ \mathrm{mL}$ ) among individuals reporting income-related food insecurity (aOR 1.44; $95 \%$ CI 0.95 , $2.19)$ but were more likely to be non-adherent to medication (aOR 1.77; 95\% CI 1.26, 2.48).

\section{Poverty and Deprivation}

Poverty and deprivation are reported as fundamentally neighbourhood or area level factors and based on contextspecific measurement tools, including the Evaluation of Deprivation and Inequalities in Health Examination Centres (EPICES). Two of nine studies reported a significant adjusted negative association with virological suppression and deprivation [95, 115]. For instance, Raho-Moussa et al. [115] found that individuals who reported either individual determinants of deprivation (specifically financial difficulties in past month) or had an EPICES score indicating residence in a deprived state were $66 \%$ (aOR $0.34 ; 95 \%$ CI 0.16 , 0.72 ) and $65 \%$ (aOR 0.35 ; 95\% CI $0.14,0.85$ ) less likely, respectively, to achieve a $\mathrm{VL}<50$ copies $/ \mathrm{mL}$, compared to people living with HIV who did not meet these measures of deprivation, after adjusting for age and medication-, and clinically-related factors. Only one study reported a significant adjusted association with medication adherence which was in a negative direction [63]. Kalichman and Grebler [63] report that individuals reporting poverty-related stress are $28 \%$ (aOR $0.72 ; 95 \%$ CI $0.59,0.89$ ) and $26 \%$ (aOR 0.74 ; $95 \%$ CI $0.62,0.88$ ) less likely to report $85 \%$ and $75 \%$ ART adherence, respectively, after adjusting for social stressors, depression, internalised AIDS stigma and drug use.

\section{Income}

Income included components of temporality (e.g., annual), ecological level (e.g., household), sources (e.g., social benefits) and quantities (e.g., $<\$ 15,000$ ). Four of 33 studies looking at income found a significant adjusted association with virological suppression [58, 77, 86, 101, 103]; three reported a negative association (lower income) and the other two a positive association (higher/mid-range income). For instance, the likelihood of virological nonsuppression among Canadian men who have sex with men earning $<\$ 15,000$ annually were 6 -times greater (aOR 6.43 ; $95 \%$ CI $2.08,19.89$ ), than those earning more, after adjusting for age, ethnicity, sexual orientation, country of birth and other characteristics [77]. However, one study [58] found people living with HIV with an annual household 
(a) Deprivation, food insecurity, income and virological suppression

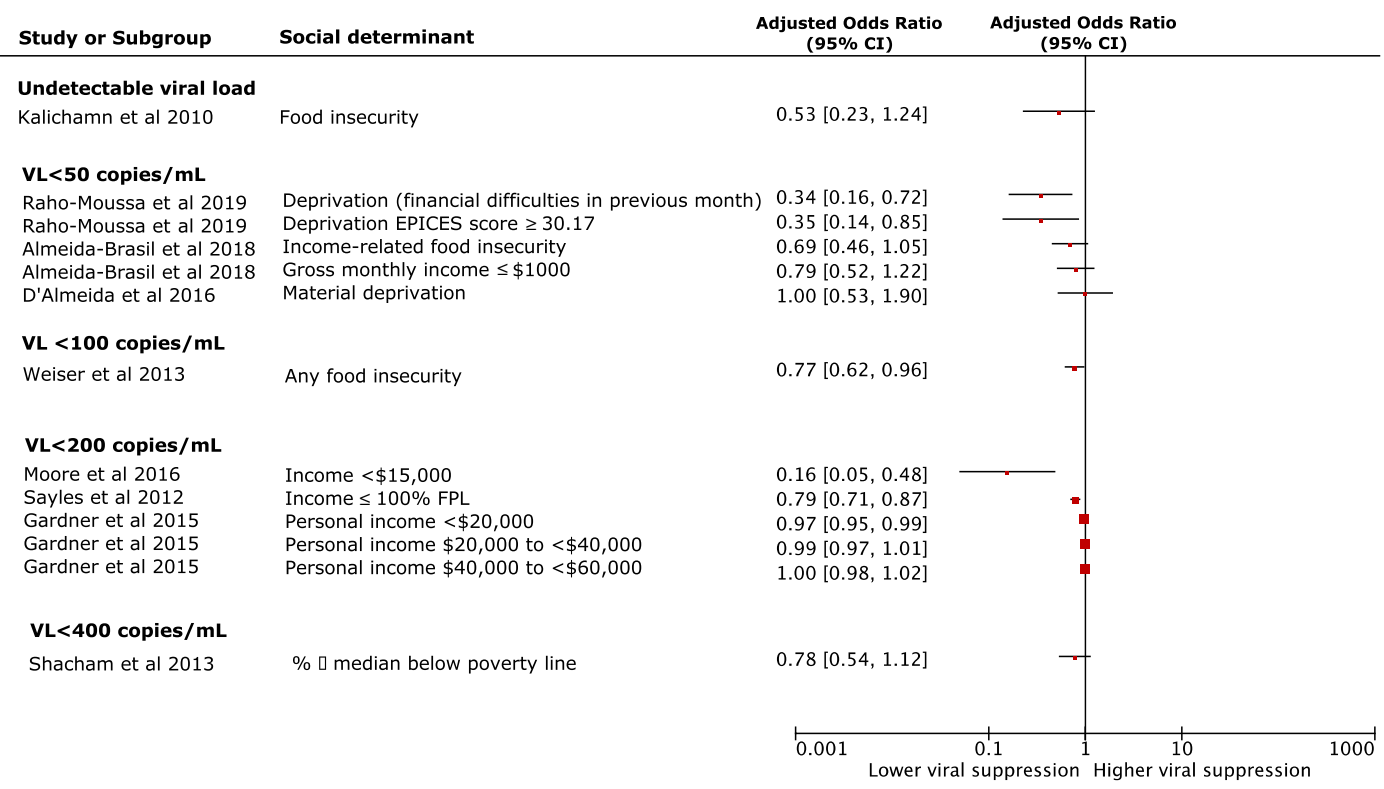

(b) Deprivation, food insecurity, income and medication adherence

\begin{tabular}{|c|c|c|c|c|c|}
\hline Study or Subgroup & Social determinant & $\begin{array}{c}\text { Adjusted Odds Ratio } \\
95 \% \text { CI } \\
\end{array}$ & $\begin{array}{r}\text { Adjusted } 0 \\
95 \% \\
\end{array}$ & $\begin{array}{l}\text { Odds Ratio } \\
\% \text { CI }\end{array}$ & \\
\hline $100 \%$ adherence & & & & & \\
\hline Uuskula et al 2012 & Income (social benefits) & $2.00[0.56,7.14]$ & - & & \\
\hline Uuskula et al 2012 & Income (relatives/partners) & $0.71[0.16,3.13]$ & . & - & \\
\hline Missed no doses, past 4 & days & & & & \\
\hline Almeida-Brasil et al 2018 & Gross monthly income $\leq \$ 1000$ & $0.96[0.69,1.35]$ & & - & \\
\hline Almeida-Brasil et al 2018 & Income-related food insecurity & $0.57[0.40,0.79]$ & $=$ & & \\
\hline Missed no doses, past 7 & days & & & & \\
\hline Kacanek et al 2019 & Annual household income $\leq \$ 10,000$ & $0.41[0.14,1.27]$ & & & \\
\hline Kacanek et al 2019 & Annual household income $>\$ 10,000$ to $\$ 40,000$ & $0.51[0.21,1.22]$ & 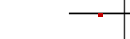 & & \\
\hline Missed no doses, past $9 c$ & days & & & & \\
\hline Surratt et al 2015 & Neighbourhood disorder & $0.98[0.96,1.00]$ & & 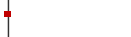 & \\
\hline $95 \%$ adherence & & & & & \\
\hline Chitsaz et al 2013 & Food insecurity & $0.97[0.61,1.54]$ & $\longrightarrow$ & 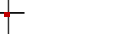 & \\
\hline Koehn et al 2020 & Food insecure & $0.47[0.24,0.93]$ & $\longrightarrow$ & & \\
\hline O'Neil et al 2012 & $<\$ 15,000$ & $0.47[0.31,0.72]$ & - & & \\
\hline $90 \%$ adherence & & & & & \\
\hline Gebo et al 2003 & Eating $<2$ meals & $0.30[0.10,0.90]$ & & & \\
\hline Gebo et al 2003 & Eating $<2$ meals (injecting drug use) & $0.06[0.01,0.52]$ & & & \\
\hline Gebo et al 2003 & Eating $<2$ meals (women) & $0.12[0.02,0.76]$ & & & \\
\hline Kalichman et al 2010 & Food insufficiency & $0.30[0.10,0.90]$ & 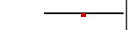 & & \\
\hline Kalcihman et al 2010 & $<\$ 1000$ & $0.80[0.32,2.00]$ & & - & \\
\hline Weiser et al 2013 & Any food insecurity & $0.68[0.54,0.84]$ & - & & \\
\hline $85 \%$ adherence & & & & & \\
\hline Kalichman \& Grebler 2010 & Poverty-related stress & $0.72[0.58,0.89]$ & - & & \\
\hline Kalichman et al 2014 & Food insecurity & $0.43[0.20,0.92]$ & & & \\
\hline $80 \%$ adherence & & & & & \\
\hline Kalichman et al 2010 & Food insuffficiency & $0.30[0.11,0.80]$ & - & & \\
\hline Kalichman et al 2010 & $<\$ 1000$ & & & & \\
\hline $75 \%$ adherence & & & & & \\
\hline Kalichman \& Grebler 2010 & Poverty-related stress & $0.74[0.62,0.88]$ & $=$ & & \\
\hline & & 0.001 & $\begin{array}{l}0.1 \\
\text { adherence }\end{array}$ & $\begin{array}{cc}1 & 10 \\
\text { More } & \text { adh }\end{array}$ & $000^{\circ}$ \\
\hline
\end{tabular}


४Fig. 5 Forest plots of likelihood (aOR) of a virological suppression and $\mathbf{b}$ medication adherence among people living with HIV who were disadvantaged, compared to more advantaged after adjusting for sociodemographic factors. EPICES Evaluation of Deprivation and Inequalities in Health Examination Centres, FPL federal poverty level, $V L$ viral load

income of $<\$ 10,000$ were significantly more likely to report virological suppression, compared to those earning $\$ 10,000-\$ 24,999$ (aOR $0.21 ; 95 \%$ CI $0.06,0.73$ ) and $\$ 25,000-\$ 49,999$ (aOR 0.11; 95\% CI 0.03, 0.52) [58]. The authors suggest that this may be due to those with lower annual household incomes being more likely to be receiving support linked to the Ryan White Program [58]. Sayles et al.[86] used federal poverty level (FPL) as a measure of income and found that uninsured people living with HIV in Los Angeles, who were receiving publicly funded healthcare through the Ryan White program, and had an income $\leq 100 \%$ FPL were $27 \%$ more likely (aOR 1.27 ; 95\% CI $1.15,1.41$ ) to be virologically non-suppressed than those with an income greater than the FPL. Five studies reported a significant adjusted association between income and medication adherence $[41,57,79,96,103]$; negative associations were found among low income individuals $[57,79,103]$ whilst, comparatively, mid-level/higher income were found to be positively associated [41, 96]. Vyas et al.[96] found individuals with a higher annual household income $(\geq \$ 10,000)$ were significantly more likely to be $\geq 90 \%$ ART adherent. The situation is less clear within the Veterans Aging Cohort Study whereby only individuals earning a mid-range annual household income $(\$ 25,000-\$ 49,999)$ were significantly more likely to be adherent to medication, compared to those earning $<\$ 6000$ [41]. A significant association was not found among the other 3 income categories [41]. Finally, Burch [103] reported whether individuals in the UK had financial stability through a proxy of having "enough money for basic needs"; they found that those who reported mostly, sometimes or not having enough were more likely to be nonadherent, compared to always having enough money.

\section{Socioeconomic Status/Position (SES/SEP)}

SES/SEP were reported across ecological levels. Two of four studies reported a significant positive adjusted association with higher/mid-range SES/SEP and viral suppression [87, 110]. Interestingly, a US study [87] found that individuals who had a "mid-range" SES which was defined by their payscale and whether they received support with healthcare costs (5-70\% co-pay) were less likely (adjusted Relative Risk [aRR] 0.39; 95\% CI 0.16, 0.94) to have a detectable HIV viral load, although this did not remain significant when considering CD4 counts $<200$. Only one study looked at adjusted associations between SES and medication adherence; Parruti et al.[113] report no significant difference (OR 0.76 ; $95 \%$ CI $0.30,2.00)$ in HAART adherence between people living with HIV in Italy with very low or low SES, compared to those with medium or high SES.

\section{Social Class}

One study [114] explored the association between social class and treatment outcomes. Persson et al.[114] found no difference in the likelihood of having CD4 counts lower than the median value among skilled and unskilled workers (defined as social class III) compared to middle range civil servants (social class II) (OR 1.5; 95\% CI 0.5, 4.9).

\section{Marginalised Sub-groups}

Some studies followed specific subgroups of individuals who are often disproportionately affected by HIV; including, the homeless, people in prisons, people who use drugs and transgender women. Oftentimes, people will identify with multiple identities (intersectionality). For instance, Marshall et al. [72] reported that homeless people living with HIV who use drugs were almost half as likely (aPR $0.55 ; 95 \%$ CI $0.42,0.71)$ to have an undetectable VL compared to those with housing, even after adjusting for sociodemographic factors and factors related to their substance use including addiction treatment. Berg et al. [45] found ART adherence rate was greater among individuals who were current or former opioid users who had lived in long-term housing even after adjusting for gender and intermediary determinants including alcohol and substance use. Finally, a small crosssection of transgender women living with HIV $(n=123)$ living in unstable housing had one of poorest virological outcomes, specifically their risk of having a detectable VL was over 7-times (aRR 7.37; 95\% CI 1.07, 50.88) that of transgender women living in stable housing [44].

\section{Risk of Bias}

Overall, 8 (9.6\%) studies $[51,60,69,81,102,111,117$, 123 ] included in the review were scored 'low quality' or had a high risk of bias. Notably, several of the cross-sectional studies were possibly affected by selection bias; for instance, investigating a small sample size or not stating the frequency of non-respondents (Additional file 7). There was heterogeneous reporting within and between studies with no standardised approach for measuring and classifying social factors (exposures), outcomes or associations which limited possible study comparisons. 


\section{Discussion}

A small proportion (10-20\%) of studies observed significant associations between material deprivation and poorer clinical outcomes. Overall, they suggest that people living with HIV who are the most materially deprived (housing, employment, deprivation, or income) display poorer viral suppression and medication adherence compared to those more advantaged. The strongest evidence is present for housing whereby 1 in 5 studies found unstable housing status was associated with poorer viral suppression; however, we found that $89 \%$ of the variability in the ORs could be explained by heterogeneity between the studies. An inconsistent association was observed for studies measuring education and adherence outcomes. A higher proportion of included studies observed significant, consistent associations between SES/SEP and virological suppression (50\%) and food security and adherence (86\%). We also found evidence that intersectionality worsens outcomes. The magnitude of associations were compounded within specific subgroups; for example, US transgender women who were homeless or marginally housed were 20-times more likely to be virologically non-suppressed than transgender women living in stable housing, after adjusting for age, race/ethnicity, history of injection drug use and health insurance status [85].

Our findings are in line with other studies including reviews which have found worsening outcomes associated with material deprivation, including unstable housing status, food insecurity and lower socioeconomic status [14, 124-126]. We find that these associations persist in high-income countries even as advanced generations of antiretrovirals become widely available, HIV prevention programmes continue to be scaled-up and HIV care evolves significantly through the digital age. For instance, in line with Krieger's ecosocial theory [27, 28], issues of agency for HIV care exacerbate inequities among US women living with HIV [127]. This may be explained by the contextspecific and interrelated nature of social determinants. For instance, school leavers ages vary across countries (from 15 to 18 years old) as does minimum wage, entitlements to welfare and state benefits and other support services available. In other words, social and cultural capital go beyond the measures of "relative deprivation" but can be more difficult to measure [128, 129]. Unlike Burch et al. [14], we did not explore health insurance as this is not a considerable barrier in countries with a universal healthcare system, such as the UK. Rather, factors such as social class drive health inequalities seen in the UK which were first described in the 1980 Black Report and later by Marmot's Reports $[3,5,130]$. Associations between structural factors (HIVrelated laws), interpersonal factors (perceived social capital) and individual outcomes (ART adherence) have also been identified across ecosocial context levels in North America which highlights the potential mechanisms of relationships between social and structural determinants [82]. Additionally, some determinants may be more directly associated with outcomes than others; for instance, some medication should be taken with food which may not be possible for somebody who is food insecure/insufficient, in turn influencing ART adherence [126].

The review had several strengths including a comprehensive search strategy and the inclusion of independent reviewers at screening, data extraction and quality assessment stages. We also grouped duplicate reports at the final stage of screening as one study and included the most recent report in the review to avoid possible publication bias. The majority of included studies were scored as low or uncertain risk of bias; however, the modified Newcastle-Ottawa scale used for cross-sectional studies has not been validated [37, 131]. Additionally, no grey literature was included, nor publications not published in English, which may have inadvertently excluded relevant studies, particularly from HIV community groups and charities. We only included observational studies, limiting the ability to make any causal inferences and potentially introducing social desirability bias of studies reliant on self-reported data only. Our review contributes to this field of knowledge but is unable to determine how determinants may or may not be causally linked but begins to suggest which determinants may interact with treatment outcomes of people living with HIV. We also recognise that social determinants are heavily interlinked, with collinearity between variables; however, we do not attempt to develop a causal pathway in this paper.

These findings re-emphasise the need for well-designed measures of social determinants in studies with evidencebased, context-specific definitions; for instance, higherincome countries (e.g., in Europe) use a 'class structural' approach to define occupation compared to low- and middleincome countries whereby occupation is highly dependent on working conditions (e.g., formal/informal sectors or environmental factors) [132]. As previously suggested by Krieger et al.[38] studies should be collecting socioeconomic data across all ecological levels and the lifecourse, treat income and poverty as dynamic, consider types of assets and wealth but also not conflate between SES and social class. We found that these recommendations were not met in most included studies and rather studies measured determinants at single timepoints or only at one ecological level. There is a clear gap for well-designed research looking at the impact of social class on treatment outcomes of people living with HIV. For instance, research into using subjective social class has found that individuals often use measures of socioeconomic position to assign status however, also take into account their current and future material and economic 
prospects which may be a more suitable, composite socioeconomic indicator [133].

Additionally, to develop a more conclusive understanding, a need remains to standardise thresholds of viral suppression across studies to allow for more detailed analyses of the direction of reported effect sizes. This would enable more robust random effects meta-analyses, and subsequent meta-synthesis, to be conducted despite issues relating to the generalisability of results and heterogeneous nature of studies. As a result, this would support the design of more appropriate, system-wide interventions and clinics to identify and support the most socioeconomically disadvantaged, and marginalised, people living with HIV. For instance, interventions focussing on the provision of stable and secure housing, rather than limiting this to adherence support for people continuing to live in precarious housing conditions which could have significant implications for HIV outcomes as well as wider mental health and wellbeing outcomes [134]. The Housing and Health Study for rental assistance found that HIV-related housing services were cost-effective as a HIV prevention intervention but also in relation to quality of life; a cost-per-QALY-saved estimated to be $\$ 62,493$ for homeless and unstably housed people living with HIV across three US cities [135, 136]. At today's exchange rate, this exceeds the UK National Institute for Health and Care Excellence (NICE) evidence-based guidelines for public health and social care services in for which as a cost-effectiveness threshold between $£ 20,000-£ 30,000$ per QALY gained [137].

Further research is required to determine to what extent person-centred and holistic HIV care improves the health and wellbeing outcomes among people living with HIV. For instance, the provision of social support services including housing, welfare and benefits advice, food and transport vouchers, alongside routine clinical monitoring to help address stigma, reduce health inequalities and ensure equitable access to HIV treatment and care.

\section{Conclusions}

Our study has shown that the contribution of measures of material deprivation on HIV treatment outcomes remains complex. There is a need to propose a causal pathway of the relationship between these factors. An ecosocial analysis would help to establish the impact of social determinants between and across ecological levels (e.g., individual, household, neighbourhood) and how these are 'embodied' by individuals across the lifecourse. Further research might then be able to disentangle how social determinants are driven by inequalities in gender, sexual orientation, social class, and race/ethnicity allowing us to build a deeper understanding of how, when, and to what extent, these determinants interact with one another. Subsequently, this would ensure the support systems and services in places for the most marginalised groups living with HIV are acceptable and have the greatest impact on service users.

Supplementary Information The online version contains supplementary material available at https://doi.org/10.1007/s10461-021-03551-y.

Acknowledgements We thank the staff in Library Services (Imperial College London) for their support with designing our search strategy. We also thank Dr Valerie Delpech (Public Health England) for her feedback on our initial approach to this review. Finally, thank you to Dr Lidia Luna Puerta for her translation of our abstract into Spanish.

Author Contributions VP, BD and HW, designed the research study. VP led the systematic review and drafted the first version of this manuscript. AS and VP conducted title, abstract and full text screening. VP extracted data which was cross-checked by EC. VP conducted the quality assessment which was cross-checked by BD. VP, BD and HW critically interpreted the results and revised the manuscript. All authors have read and approved the final manuscript.

Funding VP is supported by an ESRC LISS-DTP CASE Studentship. BD acknowledges funding from the NIHR HPRU in Chemical and Radiation Threats and Hazards (NIHR-200922); HDR UK Hub DISCOVER-NOW and infrastructure support for the Department of Epidemiology and Biostatistics provided by the NIHR Imperial Biomedical Research Centre. HW is a NIHR Senior Investigator and acknowledges support from NIHR Imperial Biomedical Research Centre, NIHR School of Public Health, NIHR Applied Research Collaborative North West London, and Wellcome Trust (UNS32973). The views expressed are those of the authors and not necessarily those of the NIHR or the Department of Health and Social Care.

Data Availability Supporting data are available from the corresponding author upon request.

Code Availability Not applicable.

\section{Declarations}

Conflict of interest The authors have no relevant financial or non-financial interests to disclose.

Ethical Approval Not applicable.

Informed Consent Not applicable.

Consent for Publication Not applicable.

Open Access This article is licensed under a Creative Commons Attribution 4.0 International License, which permits use, sharing, adaptation, distribution and reproduction in any medium or format, as long as you give appropriate credit to the original author(s) and the source, provide a link to the Creative Commons licence, and indicate if changes were made. The images or other third party material in this article are included in the article's Creative Commons licence, unless indicated otherwise in a credit line to the material. If material is not included in the article's Creative Commons licence and your intended use is not permitted by statutory regulation or exceeds the permitted use, you will need to obtain permission directly from the copyright holder. To view a copy of this licence, visit http://creativecommons.org/licenses/by/4.0/. 


\section{References}

1. Solar O, Irwin A. A conceptual framework for action on the social determinants of health. Geneva: World Health Organization; 2010. (Social Determinants of Health Discussion Paper 2 (Policy and Practice)).

2. Graham H. Social determinants and their unequal distribution: clarifying policy understandings. Milbank Q. 2004;82(1):101-24.

3. Marmot M, Allen J, Goldblatt P, Boyce T, McNeish D, Grady M, et al. Fair society, healthy lives. Amsterdam: Elsevier; 2010.

4. Marmot M, Allen J, Goldblatt P, Boyce T, McNeish D, Grady M, et al. Chapter 3: Lessons to be learned from the current Health Inequality Strategy, targets and indicators. In: Fair society, healthy lives. Amsterdam: Elsevier; 2010. p. 85-91.

5. Marmot M, Allen J, Boyce T, Goldblatt P, Morrison J. Health equity in England: the marmot review 10 years on. London: Institute of Health Equity; 2020.

6. Stuckler D, Reeves A, Loopstra R, Karanikolos M, McKee M. Austerity and health: the impact in the UK and Europe. Eur $\mathbf{J}$ Public Health. 2017;27(suppl_4):18-21.

7. Caiola C, Docherty SL, Relf M, Barroso J. Using an intersectional approach to study the impact of social determinants of health for African American mothers living with HIV. ANS Adv Nurs Sci. 2014;37(4):287-98.

8. Geter A, Sutton MY, McCree DH. Social and structural determinants of HIV treatment and care among black women living with HIV infection: a systematic review: 2005-2016. AIDS Care. 2018;30(4):409-16.

9. Robinson RS. From population to HIV: the organizational and structural determinants of HIV outcomes in sub-Saharan Africa. J Int AIDS Soc. 2011;14(2):S6.

10. Alvarez-del Arco D, Monge S, Azcoaga A, Rio I, Hernando V, Gonzalez C, et al. HIV testing and counselling for migrant populations living in high-income countries: a systematic review. Eur J Public Health. 2012;23(6):1039-45.

11. Fazel S, Geddes JR, Kushel M. The health of homeless people in high-income countries: descriptive epidemiology, health consequences, and clinical and policy recommendations. Lancet. 2014;384(9953):1529-40.

12. Zierler S, Krieger N. HIV infection in women: social inequalities as determinants of risk. Crit Public Health. 1998;8(1):13-32.

13. Krieger N. Measures of racism, sexism, heterosexism, and gender binarism for health equity research: from structural injustice to embodied harm: an ecosocial analysis. Annu Rev Public Health. 2020;41(1):37-62.

14. Burch LS, Smith CJ, Phillips AN, Johnson MA, Lampe FC. Socioeconomic status and response to antiretroviral therapy in high-income countries: a literature review. AIDS. 2016;30(8):1147-62.

15. Cahill SR, Mayer KH, Boswell SL. The Ryan white HIV/AIDS program in the age of health care reform. Am J Public Health. 2015;105(6):1078-85.

16. Bradley H, Viall AH, Wortley PM, Dempsey A, Hauck H, Skarbinski J. Ryan white HIV/AIDS program assistance and HIV treatment outcomes. Clin Infect Dis. 2016;62(1):90-8.

17. Benson C, Wang X, Dunn K, Li N, Mesana L, Lai J, et al. Antiretroviral adherence, drug resistance, and the impact of social determinants of health in HIV-1 patients in the US. AIDS Behav. 2020;24:3562.

18. Nachega JB, Uthman OA, Peltzer K, Richardson LA, Mills EJ, Amekudzi K, et al. Association between antiretroviral therapy adherence and employment status: systematic review and metaanalysis. Bull World Health Organ. 2014;93:29-41.

19. Perelson AS, Essunger P, Cao Y, Vesanen M, Hurley A, Saksela $\mathrm{K}$, et al. Decay characteristics of HIV-1-infected compartments during combination therapy. Nature. 1997;387(6629):188-91.
20. Byrd KK, Hou JG, Hazen R, Kirkham H, Suzuki S, Clay PG, et al. Antiretroviral adherence level necessary for HIV viral suppression using real-world data. J Acquir Immune Defic Syndr. 2019;82(3):245-51.

21. Joint United Nations Programme on HIV/AIDS (UNAIDS). 90-90--90: An ambitious treatment target to help end the AIDS epidemic. p. 40. https://www.unaids.org/sites/default/files/ media_asset/90-90-90_en.pdf (2014).

22. Kirby T. The UK reaches UNAIDS 90-90-90 targets. Lancet. 2018;392(10163):2427.

23. Public Health England. Trends in HIV testing, new diagnoses and people receiving HIV-related care in the United Kingdom: data to the end of December 2019. 2020;14 20:16.

24. National AIDS Trust. HIV in the UK statistics. UK HIV Statistics. https://www.nat.org.uk/about-hiv/hiv-statistics. Accessed 20 Mar 2021.

25. Eckersley R. Beyond inequality: acknowledging the complexity of social determinants of health. Soc Sci Med. 2015;147:121-5.

26. Krieger N. Epidemiology and the web of causation: has anyone seen the spider? Soc Sci Med (1982). 1994;39(7):887-903.

27. Krieger N. Theories for social epidemiology in the 21st century: an ecosocial perspective. Int J Epidemiol. 2001;30(4):668-77.

28. Krieger N. Epidemiology and the people's health: theory and context. Oxford: Oxford University Press; 2011.

29. Page MJ, McKenzie JE, Bossuyt PM, Boutron I, Hoffmann TC, Mulrow CD, et al. The PRISMA 2020 statement: an updated guideline for reporting systematic reviews. BMJ. 2021;372:n71.

30. Papageorgiou V, Singer A, Cooper E, Davies B, Ward H. A systematic review of social determinants and HIV treatment outcomes among people living with HIV in high-income countries. PROSPERO. https://www.crd.york.ac.uk/prospero/displ ay_record.php?ID=CRD42020171850 (2020). Accessed 9 June 2020.

31. World Bank. World Bank Country and Lending Groups. https:// datahelpdesk.worldbank.org/knowledgebase/articles/906519world-bank-country-and-lending-groups (2019). Accessed 19 Mar 2020.

32. Organisation for Economic, Co-operation and Development (OECD), OECD. Our global reach. https://www.oecd.org/about/ members-and-partners/. Accessed 19 Mar 2020.

33. Covidence systematic review software. Melbourne, Australia: Veritas Health Innovation. www.covidence.org

34. Review Manager (RevMan) [Computer program]. Version 5.4. The Cochrane Collaboration; 2020.

35. Deeks JJ, Higgins J, Altman DG, editors. Chapter 10: Analysing data and undertaking meta-analyses. In: Cochrane handbook for systematic reviews of interventions version 62 (updated February 2021). Cochrane. www.training.cochrane.org/handbook (2021).

36. Wells GA, Shea B, O'connell D, Peterson J, Welch V, Losos M, et al. The Newcastle-Ottawa Scale (NOS) for assessing the quality of nonrandomised studies in meta-analyses. 2013. http://www. ohri.ca/programs/clinical_epidemiology/oxford.asp (2016).

37. Modesti PA, Reboldi G, Cappuccio FP, Agyemang C, Remuzzi $\mathrm{G}$, Rapi S, et al. Panethnic differences in blood pressure in Europe: a systematic review and meta-analysis. PLoS ONE. 2016;11(1):e0147601.

38. Krieger N, Williams DR, Moss NE. Measuring social class in US public health research: concepts, methodologies, and guidelines. Annu Rev Public Health. 1997;18(1):341-78.

39. World Health Organization. Consolidated guidelines on the use of antiretroviral drugs for treating and preventing HIV infection: recommendations for a public health approach. http://apps. who.int/iris/bitstream/10665/208825/1/9789241549684_eng.pdf (2016). Accessed 10 July 2020. 
40. World Health Organization. Patient monitoring guidelines for HIV care and antiretroviral therapy (ART); 2006.

41. Keith McInnes D, Shimada SL, Rao SR, Quill A, Duggal M, Gifford AL, et al. Personal health record use and its association with antiretroviral adherence: survey and medical record data from 1871 US veterans infected with HIV. AIDS Behav. 2013;17(9):3091-100.

42. Almeida-Brasil CC, Moodie EEM, McLinden T, Hamelin A-M, Walmsley SL, Rourke SB, et al. Medication nonadherence, multitablet regimens, and food insecurity are key experiences in the pathway to incomplete HIV suppression. AIDS. 2018;32(10):1323.

43. Anderson JC, Campbell JC, Glass NE, Decker MR, Perrin N, Farley J. Impact of intimate partner violence on clinic attendance, viral suppression and CD4 cell count of women living with HIV in an urban clinic setting. AIDS Care. 2018;30(4):399-408.

44. Baguso GN, Turner CM, Santos G-M, Raymond HF, Dawson-Rose $\mathrm{C}$, Lin J, et al. Successes and final challenges along the HIV care continuum with transwomen in San Francisco. J Int AIDS Soc. 2019;22(4):e25270.

45. Berg KM, Demas PA, Howard AA, Schoenbaum EE, Gourevitch MN, Arnsten JH. Gender differences in factors associated with adherence to antiretroviral therapy. J Gen Intern Med. 2004;19(11):1111-7.

46. Blank AE, Fletcher J, Verdecias N, Garcia I, Blackstock O, Cunningham $\mathrm{C}$. Factors associated with retention and viral suppression among a cohort of HIV+ women of color. AIDS Patient Care STDS. 2015;29(Suppl 1):S27-35.

47. Chitsaz E, Meyer JP, Krishnan A, Springer SA, Marcus R, Zaller $\mathrm{N}$, et al. Contribution of substance use disorders on HIV treatment outcomes and antiretroviral medication adherence among HIVinfected persons entering jail. AIDS Behav. 2013;17(Supplement 2):S118-27.

48. Clemenzi-Allen A, Geng E, Christopoulos K, Hammer H, Buchbinder S, Havlir D, et al. Degree of housing instability shows independent 'dose-response' with virologic suppression rates among people living with human immunodeficiency virus. Open Forum Infect Dis. 2018;5(3):ofy035.

49. Creasy SL, Henderson ER, Bukowski LA, Matthews DD, Stall RD, Hawk ME. HIV Testing and ART adherence among unstably housed black men who have sex with men in the United States. AIDS Behav. 2019;23(11):3044-51.

50. Doshi RK, Milberg J, Jumento T, Matthews T, Dempsey A, Cheever LW. For many served by the Ryan white HIV/AIDS program, disparities in viral suppression decreased, 2010-14. Health Aff. 2017;36(1):116-23.

51. Dowshen N, Matone M, Luan X, Lee S, Belzer M, Fernandez MI, et al. Behavioral and health outcomes for HIV+ young transgender women (YTW) linked to and engaged in medical care. LGBT Health. 2016;3(2):162-7.

52. Fadul N, Taylor P, Kearney G. Predictors of viral load suppression in HIV-infected patient in rural Eastern North Carolina. Open Forum Infect Dis. 2017;4(Supplement 1):S421.

53. Feldman M, Thomas J, Alexy E, Irvine M. Crystal methamphetamine use and HIV medical outcomes among HIV-infected men who have sex with men accessing support services in New York. Drug Alcohol Depend. 2015;147:266-71.

54. Feller DJ, Agins BD. Understanding determinants of racial and ethnic disparities in viral load suppression: a data mining approach. J Int Assoc Provid AIDS Care. 2016;16(1):23-9.

55. Gardner S, Rachlis B, Light L, Raboud J, Cooper C, Kendall C, et al. Impact of social determinants of health and substance use on HIV viral suppression (SVL). Can J Infect Dis Med Microbiol. 2015;26(Suppl. SB):38B.

56. Gebo KA, Keruly J, Moore RD. Association of social stress, illicit drug use, and health beliefs with nonadherence to antiretroviral therapy. J Gen Intern Med. 2003;18(2):104-11.
57. Golin CE, Liu H, Hays RD, Miller LG, Beck CK, Ickovics $\mathrm{J}$, et al. A prospective study of predictors of adherence to combination antiretroviral medication. J Gen Intern Med. 2002;17(10):756-65.

58. Haider MR, Brown MJ, Harrison S, Yang X, Ingram L, Bhochhibhoya A, et al. Sociodemographic factors affecting viral load suppression among people living with HIV in South Carolina. AIDS Care. 2019;33:1-9.

59. Hussen SA, Easley KA, Smith JC, Shenvi N, Harper GW, Camacho-Gonzalez AF, et al. Social capital, depressive symptoms, and HIV viral suppression among young black, gay, bisexual and other men who have sex with men living with HIV. AIDS Behav. 2018;22(9):3024-32.

60. Iralu J, Duran B, Pearson CR, Jiang YZ, Foley K, Harrison M. Risk factors for HIV disease progression in a rural southwest American Indian population. Public Health Rep. 2010;125(Supplement 4):43-50.

61. Johnson M, Catz S, Remien RH, Rotheram-Borus M, Morin $\mathrm{CE}$, et al. Theory-guided, empirically supported avenues for intervention on HIV medication nonadherence: findings from the Healthy Living Project. AIDS Patient Care STDs. 2003;17(12):645-56

62. Kacanek D, YanLing H, Malee K, Mellins CA, Smith R, Garvie $\mathrm{PA}$, et al. Nonadherence and unsuppressed viral load across adolescence among US youth with perinatally acquired HIV. AIDS. 2019;33(12):1923-34.

63. Kalichman SC, Grebler T. Stress and poverty predictors of treatment adherence among people with low-literacy living with HIV/ AIDS. Psychosom Med. 2010;72(8):810-6.

64. Kalichman SC, Cherry C, Amaral C, White D, Kalichman MO, Pope $\mathrm{H}$, et al. Health and treatment implications of food insufficiency among people living with HIV/AIDS, Atlanta, Georgia. J Urban Health. 2010;87(4):631-41.

65. Kalichman S, Hernandez D, Cherry C, Kalichman M, Washington $\mathrm{C}$, Grebler T. Food insecurity and other poverty indicators among people living with HIV/AIDS: effects on treatment and health outcomes. J Community Health. 2014;39(6):1133-9.

66. Kleeberger CA, Buechner J, Palella F, Detels R, Riddler S, Godfrey $\mathrm{R}$, et al. Changes in adherence to highly active antiretroviral therapy medications in the Multicenter AIDS Cohort Study*. AIDS. 2004;18(4):683.

67. Koehn K, McLinden T, Collins AB, McDougall P, Baltzer-Turje $\mathrm{R}$, Miewald C, et al. Assessing the impact of food insecurity on HIV medication adherence in the context of an integrated care programme for people living with HIV in Vancouver, Canada. Public Health Nutr. 2020;23(4):683-90.

68. Kyser M, Buchacz K, Bush TJ, Conley LJ, Hammer J, Henry $\mathrm{K}$, et al. Factors associated with non-adherence to antiretroviral therapy in the SUN study. AIDS Care. 2011;23(5):601-11.

69. Lacombe-Duncan A, Bauer GR, Logie CH, Newman PA, Shokoohi M, Kay ES, et al. The HIV care cascade among transgender women with HIV in Canada: a mixed-methods study. AIDS Patient Care STDs. 2019;33(7):308-22.

70. Lim S, Nash D, Hollod L, Harris TG, Lennon MC, Thorpe LE. Influence of jail incarceration and homelessness patterns on engagement in HIV care and HIV viral suppression among New York City adults living with HIV/AIDS. PLoS ONE. 2015;10(11):e0141912.

71. Ludema C, Cole SR, Eron JJJ, Edmonds A, Holmes GM, Anastos $\mathrm{K}$, et al. Impact of health insurance, ADAP, and income on HIV viral suppression among US women in the women's interagency HIV study, 2006-2009. JAIDS. 2016;73(3):307-12.

72. Marshall BDL, Elston B, Dobrer S, Parashar S, Hogg RS, Montaner JSG, et al. The population impact of eliminating homelessness on HIV viral suppression among people who use drugs. AIDS. 2016;30(6):933-41. 
73. McCoy K, Waldrop-Valverde D, Balderson BH, Mahoney C, Catz S. Correlates of antiretroviral therapy adherence among HIV-infected older adults. J Int Assoc Provid AIDS Care. 2016;15(3):248-55.

74. Miller CL, Spittal PM, Wood E, Chan K, Schechter MT, Montaner JSG, et al. Inadequacies in antiretroviral therapy use among Aboriginal and other Canadian populations. AIDS Care. 2006;18(8):968-76.

75. Mimiaga MJ, August Oddleifson D, Meersman SC, Silvia A, Hughto JMW, Landers S, et al. Multilevel barriers to engagement in the HIV care continuum among residents of the state of Rhode Island living with HIV. AIDS Behav. 2019;24:1133.

76. Mohammed H, Kieltyka L, Richardson-Alston G, Magnus M, Fawal H, Vermund SH, et al. Adherence to HAART among HIVinfected persons in Rural Louisiana. AIDS Patient Care STDs. 2004;18(5):289-96.

77. Moore DM, Cui Z, Lachowsky N, Raymond HF, Roth E, Rich A, et al. HIV community viral load and factors associated with elevated viremia among a community-based sample of men who have sex with men in Vancouver, Canada. JAIDS. 2016;72(1):87-95.

78. Nyaku M, Beer L, Shu F. Non-persistence to antiretroviral therapy among adults receiving HIV medical care in the United States. AIDS Care. 2019;31(5):599-608.

79. O'Neil CR, Palmer AK, Coulter S, O'Brien N, Shen A, Zhang W, et al. Factors associated with antiretroviral medication adherence among HIV-positive adults accessing highly active antiretroviral therapy (HAART) in British Columbia, Canada. J Int Assoc Phys AIDS Care. 2012;11(2):134-41.

80. Oliver C, Rebeiro PF, Hopkins MJ, Byram B, Carpenter L, Clouse K, et al. Substance use, demographic and socioeconomic factors are independently associated with postpartum HIV care engagement in the Southern United States, 1999-2016. Open forum Infect Dis. 2019;6(2):ofz023.

81. Phillips JC. Antiretroviral therapy adherence: testing a social context model among black men who use illicit drugs. J Assoc Nurses AIDS Care. 2011;22(2):100-27.

82. Phillips JC, Webel A, Rose CD, Corless IB, Sullivan KM, Voss $\mathrm{J}$, et al. Associations between the legal context of HIV, perceived social capital, and HIV antiretroviral adherence in North America. BMC Public Health. 2013;13(1):1-16.

83. Rebeiro PF, Howe CJ, Rogers WB, Bebawy SS, Turner M, Kheshti A, et al. The relationship between adverse neighborhood socioeconomic context and HIV continuum of care outcomes in a diverse HIV clinic cohort in the Southern United States. AIDS Care. 2018;30(11):1426-34.

84. Robinson AC, Knowlton AR. Gender differences in psychosocial factors associated with HIV viral suppression among AfricanAmerican injection drug users. AIDS Behav. 2016;20(2):385-94.

85. Santos GM, Wilson EC, Rapues J, Macias O, Packer T, Raymond HF. HIV treatment cascade among transgender women in a San Francisco respondent driven sampling study. Sex Transm Infect. 2014;90(5):430-3.

86. Sayles JN, Rurangirwa J, Kim M, Kinsler J, Oruga R, Janson M. Operationalizing treatment as prevention in Los Angeles county: antiretroviral therapy use and factors associated with unsuppressed viral load in the Ryan white system of care. AIDS Patient Care STDS. 2012;26(8):463-70.

87. Schafer KR, Brant J, Gupta S, Thorpe J, Winstead-Derlega C, Pinkerton R, et al. Intimate partner violence: a predictor of worse HIV outcomes and engagement in care. AIDS Patient Care STDs. 2012;26(6):356-65.

88. Shacham E, Nurutdinova D, Onen N, Stamm K, Overton ET. The interplay of sociodemographic factors on virologic suppression among a U.S. outpatient HIV clinic population. AIDS Patient Care STDs. 2010;24(4):229-35.
89. Shacham E, Lian M, Onen NF, Donovan M, Overton ET. Are neighborhood conditions associated with HIV management? HIV Med. 2013;14(10):624-32.

90. Singh N, Berman SM, Swindells S, Justis JC, Mohr JA, Squier $\mathrm{C}$, et al. Adherence of human immunodeficiency virus: infected patients to antiretroviral therapy. Clin Infect Dis. 1999;29(4):824-30.

91. Stone VE, Hogan JW, Schuman P, Rompalo AM, Howard AA, Korkontzelou C, et al. Antiretroviral regimen complexity, self-reported adherence, and HIV patients' understanding of their regimens: survey of women in the her study. JAIDS. 2001;28(2):124-31

92. Storholm ED, Bogart LM, Mutchler MG, Klein DJ, GhoshDastidar B, McDavitt B, et al. Antiretroviral adherence trajectories among Black Americans living with HIV. AIDS Behav. 2019;23(8):1985-97.

93. Sunil TS, McGehee MA. Social and religious support on treatment adherence among HIV/AIDS patients by race/ethnicity. J HIV/AIDS Soc Serv. 2007;6(1/2):83-99.

94. Surratt HL, Kurtz SP, Levi-Minzi MA, Chen MX. Environmental influences on HIV medication adherence: the role of neighborhood disorder. Am J Public Health. 2015;105(8):1660-6.

95. Tymejczyk O, Jamison K, Pathela P, Braunstein S, Schillinger JA, Nash D. HIV care and viral load suppression after sexual health clinic visits by out-of-care HIV-positive persons. AIDS Patient Care STDs. 2018;32(10):390-8.

96. Vyas KJ, Limneos J, Qin HF, Mathews WC. Assessing baseline religious practices and beliefs to predict adherence to highly active antiretroviral therapy among HIV-infected persons. AIDS Care. 2014;26(8):983-7.

97. Wagoner N, Elopre L, Westfall A, Mugavero M, Turan J, Hook E. Reported church attendance at the time of entry into HIV care is associated with viral load suppression at 12 months. AIDS Behav. 2016;20(8):1706-12.

98. Weiser SD, Yuan C, Guzman D, Frongillo EA, Riley ED, Bangsberg DR, et al. Food insecurity and HIV clinical outcomes in a longitudinal study of urban homeless and marginally housed HIV-infected individuals. AIDS. 2013;27(18):2953-8.

99. Whelan BM, Hebert PL, Ahrens KR, Katz DA, Buskin SE, Golden MR, et al. Predictors of failure to reach viral suppression within 1 year after human immunodeficiency virus diagnosis: a surveillance-based analysis. Sex Transm Dis. 2019;46(11):728-32.

100. Wilson EC, Turner C, Arayasirikul S, Woods T, Nguyen T, Lin $\mathrm{R}$, et al. Housing and income effects on HIV-related health outcomes in the San Francisco Bay Area: findings from the SPNS transwomen of color initiative. AIDS Care. 2018;30(11):1356-9.

101. Yehia BR, Schranz AJ, Momplaisir F, Keller SC, Gross R, Frank $\mathrm{I}$, et al. Outcomes of HIV-infected patients receiving care at multiple clinics. AIDS Behav. 2014;18(8):1511-22.

102. Abgrall S, Fugon L, Lele N, Carde E, Bentata PO, et al. Risk factors for adherence failure in $\mathrm{HIV}$-infected sub-Saharan migrants living in France and travelling back to their native country. Int J STD AIDS. 2014;25(5):389-90.

103. Burch LS. Impact of gender, sexual orientation and socio-economic factors on HIV treatment outcomes in the UK [Internet] [Thesis (Doctoral)]. University of London, University College London (United Kingdom). https://discovery.ucl.ac.uk/id/eprint/ 10041026 (2018)

104. Carrieri M, Chesney M, Spire B, Loundou A, Sobel A, Lepeu $\mathrm{G}$, et al. Failure to maintain adherence to HAART in a cohort of French HIV-positive injecting drug users. Int J Behav Med. 2003;10(1):1-14.

105. Collazos J, Asensi V, Carton JA, Ibarra S. The influence of the patients' educational levels on socioeconomic, 
clinical, immunological and virological endpoints. AIDS Care. 2009;21(4):511-9.

106. D'Almeida KW, Lert F, Spire B, Dray-Spira R. Determinants of virological response to antiretroviral therapy: socio-economic status still plays a role in the era of cART Results from the ANRS-VESPA 2 study, France. Antivir Ther. 2016;21(8):661-70.

107. Del Amo on behalf of The Socio-economic Inequalities and HIV Working Group for Collaboration of Observational HIV Epidemiological Research in Europe (COHERE) in Euro-Coord. Inequalities by educational level in response to combination antiretroviral treatment and survival in HIV-positive men and women in Europe. AIDS. 2017;31(2):253-62.

108. Dorz S, Lazzarini L, Cattelan A, Meneghetti F, Novara C, Concia E, et al. Evaluation of adherence to antiretroviral therapy in Italian HIV patients. AIDS Patient Care STDs. 2003;17(1):33-41.

109. Gordillo V, del Amo J, Soriano V, Gonzalez-Lahoz J. Sociodemographic and psychological variables influencing adherence to antiretroviral therapy. AIDS. 1999;13(13):1763-9.

110. Gueler A, Schoeni-Affolter F, Moser A, Bertisch B, Bucher HC, Calmy A, et al. Neighbourhood socio-economic position, late presentation and outcomes in people living with HIV in Switzerland. AIDS (London, England). 2015;29(2):231-8.

111. Jansen K, Brockmeyer NH, Dlugay V, Stoll M, Pauli R, Golz $\mathrm{J}$, et al. Poorer clinical outcomes of HIV-positive patients (PLWHA) having lower income: results of an analysis on the basis of the KompNet cohort. HIV Med. 2009;10(SUPPL. 2): 153 .

112. Papadopoulou A. Adherence to combination therapies in people with HIV/AIDS [Internet]. [Thesis (Doctoral)]. University of London, University College London (United Kingdom). https:// discovery.ucl.ac.uk/id/eprint/10105419/ (2000)

113. Parruti G, Manzoli L, Marani TP, D'Amico G, Rotolo S, Graziani $\mathrm{V}$, et al. Long-term adherence to first-line highly active antiretroviral therapy in a hospital-based cohort: predictors and impact on virologic response and relapse. AIDS Patient Care STDs. 2006;20(1):48-57.

114. Persson L, Gullberg B, Hanson BS, Moestrup T, Ostergren PO. HIV infection: social network, social support, and CD4 lymphocyte values in infected homosexual men in Malmo, Sweden. J Epidemiol Community Health. 1994;48(6):580-5.

115. Raho-Moussa M, Guiguet M, Michaud C, Honoré P, Palacios C, Boué $\mathrm{F}$, et al. Respective roles of migration and social deprivation for virological non-suppression in HIV-infected adults on antiretroviral therapy in France. PLoS ONE. 2019;14(3):e0213019.

116. Saracino A, Zaccarelli M, Lorenzini P, Bandera A, Marchetti G, Castelli F, et al. Impact of social determinants on antiretroviral therapy access and outcomes entering the era of universal treatment for people living with HIV in Italy. BMC Public Health. 2018;18(1):870.

117. Sellier P, Clevenbergh P, Ljubicic L, Simoneau G, Evans J, Delcey $\mathrm{V}$, et al. Comparative evaluation of adherence to antiretroviral therapy in sub-Saharan African native HIV-infected patients in France and Africa. Clin Infect Dis. 2006;43(5):654-7.

118. Sherr L, Clucas C, Lampe F, Harding R, Johnson M, Fisher M, et al. Gender and mental health aspects of living with HIV disease and its longer-term outcomes for UK heterosexual patients. Women Health. 2012;52(3):214-33.

119. Sobrino-Vegas P, Rodriguez-Urrego J, Berenguer J, Caro-Murillo AM, Blanco JR, Viciana P, et al. Educational gradient in HIV diagnosis delay, mortality, antiretroviral treatment initiation and response in a country with universal health care. Antivir Ther. 2012;17(1):1-8.

120. Spire B, Duran S, Souville M, Leport C, Raffi F, Moatti J-P, et al. Adherence to highly active antiretroviral therapies (HAART) in
HIV-infected patients: from a predictive to a dynamic approach. Soc Sci Med. 2002;54(10):1481-96.

121. Uuskula A, Laisaar K-T, Raag M, Smidt J, Semjonova S, Kogan $\mathrm{J}$, et al. Antiretroviral therapy (ART) adherence and correlates to nonadherence among people on ART in Estonia. AIDS Care. 2012;24(12):1470-9.

122. Siefried KJ, Mao L, Kerr S, Cysique LA, Gates TM, McAllister $\mathrm{J}$, et al. Socioeconomic factors explain suboptimal adherence to antiretroviral therapy among HIV-infected Australian adults with viral suppression. PLoS ONE. 2017;12(4):e0174613.

123. Yang HJ, Bang JH. Factors associated with medication adherence in patients with human immunodeficiency virus in South Korea. AIDS Care. 2017;29(10):1315-9.

124. Aidala AA, Wilson MG, Shubert V, Gogolishvili D, Globerman $\mathrm{J}$, Rueda S, et al. Housing status, medical care, and health outcomes among people living with HIV/AIDS: a systematic review. Am J Public Health. 2015;106(1):e1-23.

125. Leaver CA, Bargh G, Dunn JR, Hwang SW. The effects of housing status on health-related outcomes in people living with HIV: a systematic review of the literature. AIDS Behav. 2007;11(2):85-100.

126. Singer AW, Weiser SD, McCoy SI. Does food insecurity undermine adherence to antiretroviral therapy? A systematic review. AIDS Behav. 2015;19(8):1510-26.

127. Adimora AA, Ramirez C, Poteat T, Archin NM, Averitt D, Auerbach JD, et al. HIV and women in the USA: what we know and where to go from here. Lancet. 2021;397(10279):1107-15.

128. Scambler G. Sociology, social class, health inequalities, and the avoidance of "Classism." Front Sociol. 2019;4:56.

129. Bourdieu P. The forms of capital. In: Apple MW, Ball SJ, Gandin LA, editors. Handbook of theory and research for the sociology of education. Westport: Greenwood Press; 1986. p. 241-58.

130. Black SD. Inequalities in health: report of a Research Working Group. Department of Health and Social Security; 1980.

131. Moskalewicz A, Oremus M. No clear choice between NewcastleOttawa Scale and Appraisal Tool for Cross-Sectional Studies to assess methodological quality in cross-sectional studies of health-related quality of life and breast cancer. J Clin Epidemiol. 2020;120:94-103.

132. Bonnefoy J, Morgan A, Kelly MP, Butt J, Bergman V. Constructing the evidence base on the social determinants of health: a guide. Measurement and Evidence Knowledge Network (MEKN); 2007.

133. Singh-Manoux A, Adler NE, Marmot MG. Subjective social status: its determinants and its association with measures of ill-health in the Whitehall II study. Soc Sci Med. 2003;56(6):1321-33.

134. Quinn KG, DiFranceisco W, Spector A, Bendixen A, Peters A, Dickson-Gomez J. The effect of various supportive housing models on ART adherence among persons living with HIV in Supportive housing. Med Care. 2021;59:S124.

135. Holtgrave DR, Briddell K, Little E, Bendixen AV, Hooper M, Kidder DP, et al. Cost and threshold analysis of housing as an HIV prevention intervention. AIDS Behav. 2007;11(2):162-6.

136. Holtgrave DR, Wolitski RJ, Pals SL, Aidala A, Kidder DP, Vos $\mathrm{D}$, et al. Cost-utility analysis of the housing and health intervention for homeless and unstably housed persons living with HIV. AIDS Behav. 2013;17(5):1626-31.

137. National Institute for Health and Care Excellence. Guide to the methods of technology appraisal. p. 35. http://nice.org.uk/proce ss/pmg9 (2013)

Publisher's Note Springer Nature remains neutral with regard to jurisdictional claims in published maps and institutional affiliations. 